Article

\title{
Urea Activation by an External Bronsted Acid: Breaking Self-Association and Tuning Catalytic Performance
}

\author{
Isaac G. Sonsona ${ }^{1,2} \mathbb{E}^{\mathbb{D}}$, Eugenia Marqués-López ${ }^{1} \mathbb{E}^{\mathbb{D}}$, Marleen Häring ${ }^{2}$, David Díaz Díaz ${ }^{2,3, *}$ and \\ Raquel P. Herrera $1, *$ (1) \\ 1 Laboratorio de Organocatálisis Asimétrica, Departamento de Química Orgánica, Instituto de Síntesis \\ Química y Catálisis Homogénea (ISQCH) CSIC-Universidad de Zaragoza, C/ Pedro Cerbuna 12, \\ 50009 Zaragoza, Spain; sonsona@unizar.es (I.G.S.); mmaamarq@unizar.es (E.M.-L.) \\ 2 Institut für Organische Chemie, Universität Regensburg Universitätsstr. 31, 93053 Regensburg, Germany; \\ Marleen.Haering@chemie.uni-regensburg.de \\ 3 Institute of Advanced Chemistry of Catalonia-Spanish National Research Council (IQAC-CSIC), \\ Jordi Girona 18-26, 08034 Barcelona, Spain \\ * Correspondence: David.Diaz@chemie.uni-regensburg.de (D.D.D.); raquelph@unizar.es (R.P.H.); \\ Tel.: +49-941-943-4373 (D.D.D.); Tel.: +34-976-761-190 (R.P.H.)
}

Received: 8 July 2018; Accepted: 25 July 2018; Published: 28 July 2018

\begin{abstract}
In this work, we hypothesize that Brønsted acids can activate urea-based catalysts by diminishing its self-assembly tendency. As a proof of concept, we used the asymmetric Friedel-Crafts alkylation of indoles with nitroalkenes as a benchmark reaction. The resulting 3-substituted indole derivatives were obtained with better results due to cooperative effects of the chiral urea and a Brønsted acid additive. Such synergy has been rationalized in terms of disassembly of the supramolecular catalyst aggregates, affording a more acidic and rigid catalytic complex.
\end{abstract}

Keywords: Brønsted acids; Friedel-Crafts; organocatalysis; self-association; synergy; urea

\section{Introduction}

Asymmetric organocatalysis has become a powerful synthetic strategy over the last decade, being crucial for the development of new catalytic processes [1-13]. Among different families of organocatalysts [14], those acting by hydrogen bond interactions represent a noteworthy part of the overall developed organocatalysts [15-17]. One of the main organocatalytic structures covering this large group are (thio)urea derivatives [18-34]. After the pioneering work of Curran's group on the use of urea as an organocatalyst [35,36], a number of considerable efforts have been devoted to the design and synthesis of new (thio)urea structures as suitable catalysts for a series of important enantioselective processes [18-34]. It is remarkable that the works reported by Etter's group, where they were able to get co-crystal complexes with a urea and a variety of hydrogen bond acceptors, were the real starting point for the development of this field [37-40].

Most of the works in this field have so far focused on the development of more reactive catalytic systems in order to overcome disadvantages exhibited by organocatalysis [41], such as the necessity of high catalyst loadings and ensuing low turnover rates [42]. In this sense, progress has been made on modification of the (thio)ureas skeleton in order to increase their acidity. Within this context, more efficient catalysts were prepared, on introducing internal acidic elements (Figure 1). For instance, taking our catalyst 1a [43-51] as a model, subsequent analogues 2 [52], 3 [53] and 4 [54] were designed and have been proved to increase catalytic activity. Using this approach, the authors changed the most 
acidic moiety of the model catalyst (i.e., 3,5-bis- $\mathrm{CF}_{3}$-phenyl group) for different acidic moieties, while retaining the aminoindanol structure (Figure 1) [55,56].

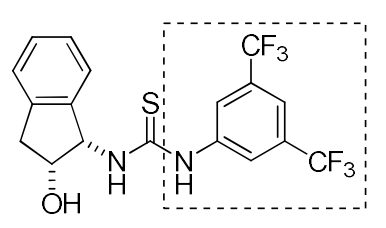

$1 a$

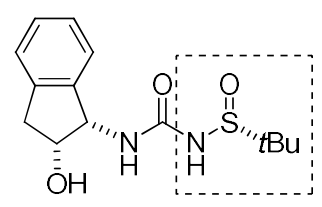

2
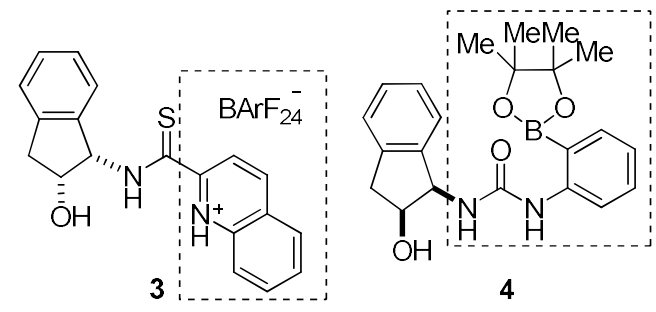

4

Figure 1. Comparative variation of acidity in (thio)urea structures.

In this respect, Sigman and co-workers demonstrated that both the reaction rate and the enantioselectivity could be correlated to catalyst acidity and it could be efficiently used for the tuning and design of new catalyst structures for hydrogen-bond-catalyzed enantioselective reactions [57].

Among the most appealing organocatalyzed reactions, the Friedel-Crafts alkylation reaction has received great attention and is a very efficient strategy for $C-C$ bond formation [58-61]. Based on our previous experience using (thio)urea catalysts [43-51,62-66], we reported a pioneering concept regarding the cooperative effect between a Brønsted acid additive and a chiral thiourea organocatalyst [45]. In this work, we hypothesize that similar beneficial effects could take place with urea organocatalysts in combination with a Brønsted acid, which could activate the urea by diminishing significantly its self-association tendency and, therefore, increasing its acidity.

\section{Results and Discussion}

\subsection{Cooperative Effect in the Mixture (Urea Catalyst + Brønsted Acid)}

We have previously studied both (thio)urea-catalyzed Friedel-Crafts-type alkylation reactions (Figure 2) [43-51]. However, the poorer results obtained with the ureas in comparison with thiourea analogues made us discard this family of structures in successive studies. The unfavorable results found with ureas have been explained based on the most acidic $\mathrm{N}-\mathrm{H}$ protons in the thioureas [67] and their less tendency to self-aggregate due to lower electron density on the sulfur atom [68-70]. Hence, it is not surprising to find more thiourea-based organocatalysts than ureas reported in the literature [16].<smiles>FC(F)(F)c1cc(NC(=S)Nc2cc(C(F)(F)F)cc(C(F)(F)F)c2)cc(C(F)(F)F)c1</smiles>

vs<smiles>O=C(Nc1cc(C(F)(F)F)cc(C(F)(F)F)c1)Nc1cc(C(F)(F)F)cc(C(F)(F)F)c1</smiles><smiles>O=C(Nc1cc(C(F)(F)F)cc(C(F)(F)F)c1)N[C@H]1c2ccccc2CC1O</smiles>

vs<smiles>O=C(Nc1cc(C(F)(F)F)cc(C(F)(F)F)c1)NC1c2ccccc2CC1O</smiles>

Figure 2. Thiourea and urea catalysts previously tested in Friedel-Crafts-type alkylation reactions.

As a matter of fact, self-association of ureas has been identified as the major drawback for hydrogen-bonding organocatalysis (Figure 3, I) [71,72]. Our previous results obtained with thioureas motivated us to investigate whether the addition of a Brønsted acid hampers the hydrogen-bonding 
pattern of the urea, allowing an equilibrium with free molecules in solution and/or smaller and soluble aggregates. In addition, molecules of "free" urea could be activated by a stronger proton donor (II), disrupting the interactions between neighboring urea molecules and, thus, increasing their efficiency as a hydrogen-bonding organocatalyst (Figure 3). In principle, the activation mode III should also be considered, since it was proposed by others when using thiourea catalysts and carboxylic acids [73-78].
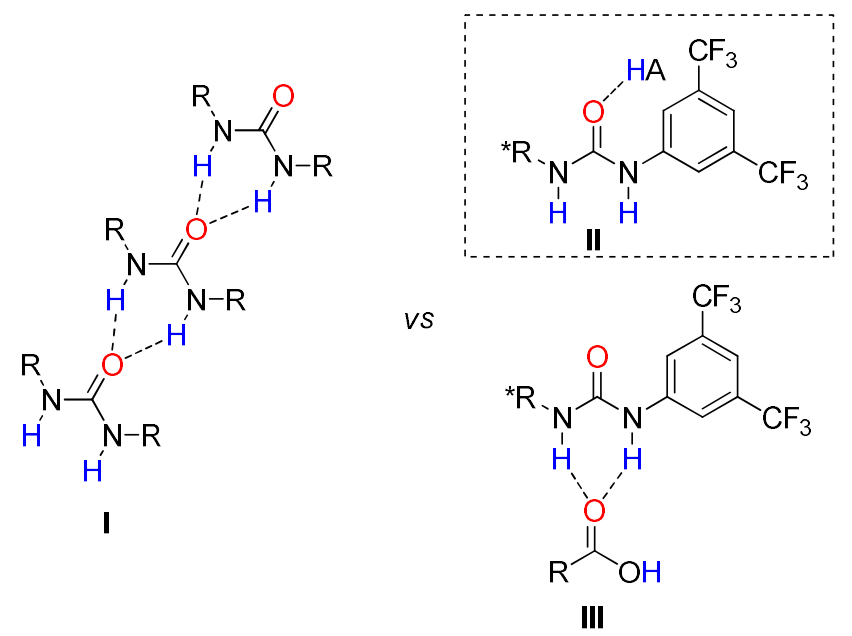

Figure 3. Mechanistic hypothesis.

To this aim, we explored in detail the Friedel-Crafts alkylation of indole 6a with nitrostyrene 7a using urea catalyst $\mathbf{1} \mathbf{b}$, both in the absence and in the presence of an external Brønsted acid (Scheme 1).

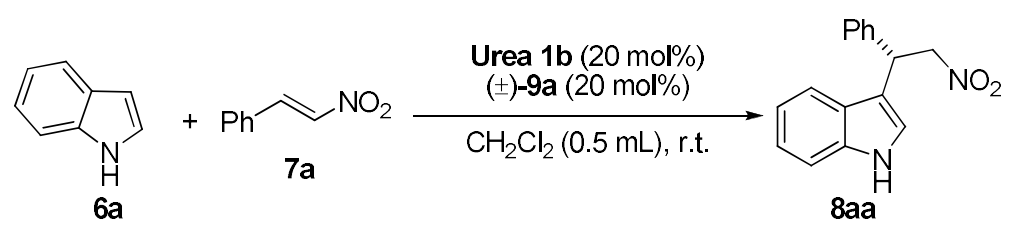<smiles>O=C(O)C(O)c1ccccc1</smiles>

$( \pm)-9 a$ 3 days yield $30 \%$ ee $0 \%$

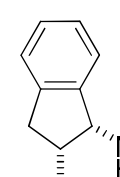

Oे<smiles>NC(=O)Nc1cc(C(F)(F)F)cc(C(F)(F)F)c1</smiles>

3 days yield $37 \%$ ee $32 \%(S)$

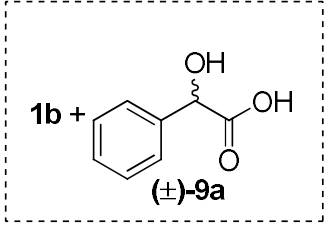

3 days yield $44 \%$ ee $52 \%(S)$

Scheme 1. Exploring the urea-catalyzed Friedel-Crafts-type alkylation reaction in the presence of a Brønsted acid.

We were delighted to observe a positive effect when using $\mathbf{1 b}$ in the presence of acid $( \pm)$-mandelic acid (9a). Interestingly, the enantiomer S (product 8aa) obtained when using complex $\mathbf{1 b}( \pm)$-mandelic acid $(\mathbf{9 a})$ was the same when using only urea $\mathbf{1} \mathbf{b}$.

At this point, we decided to explore the different parameters that could influence this activation mode. Thus, we first studied the effect of the solvent, since polarity might play an important role in governing the interaction between catalysts and reagents (Table 1). 
Table 1. Screening of catalytic complex $\mathbf{1 b} \cdot( \pm)-9 \mathbf{a}$ in different solvents. ${ }^{\text {a. }}$

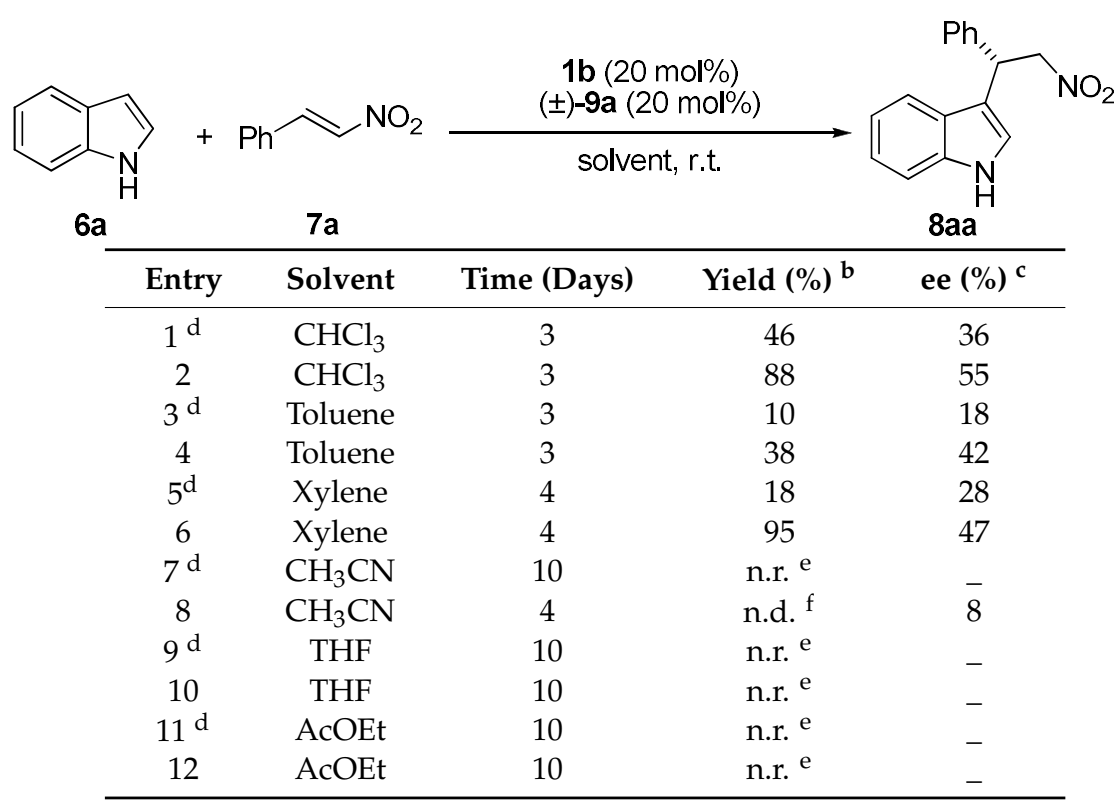

\footnotetext{
${ }^{\mathrm{a}}$ Unless specified, see Experimental Section; ${ }^{\mathrm{b}}$ After isolation by column chromatography; ${ }^{\mathrm{c}}$ Determined by chiral HPLC analysis (Chiralpak IA, Hex:iPrOH 90:10, $1 \mathrm{~mL} / \mathrm{min}$ ); ${ }^{\mathrm{d}}$ Reaction performed in the absence of mandelic acid; ${ }^{\mathrm{e}}$ n.r. $=$ Not reaction observed $;{ }^{\mathrm{f}}$ n.d. $=$ Not determined .
}

A lack of reactivity in polar solvents, with high complexing character, was observed even when the solubility of the urea was certainly higher in those solvents (Table 1, entries 7-12). Thus, the rupture or weakening of the hydrogen interactions between the catalyst and the reagents seems to be higher in these solvents, hampering the reaction. In sharp contrast, good results were achieved on using less coordinating solvents, such as toluene and xylene (Table 1, entries 4-6). Finally, $\mathrm{CHCl}_{3}$ provided the best results (Table 1, entry 2) and, we hence selected this solvent for further studies. It is remarkable that, in all cases, better results were obtained in terms of enantioselectivity and reactivity using catalyst $\mathbf{1 b}$ in the presence of mandelic acid ( \pm )-9a (e.g. entries $2,4,6,8$ vs. entries 1, 3, 5, 7). Interestingly, the same enantiomeric product $S$ was obtained with thiourea $1 \mathbf{a}$ and urea $\mathbf{1 b}$, as well as with a mixture of urea $\mathbf{1 b}$ and Brønsted acid ( \pm )-9a. These results suggest that urea catalyst, and not the Brønsted acid, drives the enantioselectivity of the process.

Furthermore, we extended the exploration of this catalytic system using different Brønsted acids. Scheme 2 shows the results obtained with representative derivatives of acetic acid as the structural core of the mandelic acid $( \pm)-9 \mathbf{a}$.

The results shown in Scheme 2 revealed a cooperative effect between urea $\mathbf{1 b}$ and all external acids used, although without a clear correlation with the pKa of the acid (Scheme S1). (R)- and (S)-mandelic acid $9 \mathbf{a}$ were tested in order to explore the match and mismatch effect. In both cases, the $S$ enantiomer and the same results were obtained, suggesting that chirality is induced only by catalyst $\mathbf{1} \mathbf{b}$. With this experiment, we discarded activation mode III (Figure 3), since in such case the chirality of the acid would be expected to influence the absolute configuration of the final products. In contrast, these results are in agreement with the activation mode II (Figure 3), where Brønsted acid could be activating urea 1b. Remarkably, $(S)-\mathbf{9 c}$ and $( \pm)-\mathbf{9 d}$ also presented similar results than $( \pm)-\mathbf{9 a}$. However, further studies were done using mandelic acid since, being the cheaper acid, its structure seems to be one of the most influential on urea self-aggregation, providing good results in terms of enantioselectivity and reactivity.

Table 2 summarizes the effect of temperature on the behavior of the complex $\mathbf{1 b} \cdot( \pm)$-mandelic acid (9a). 


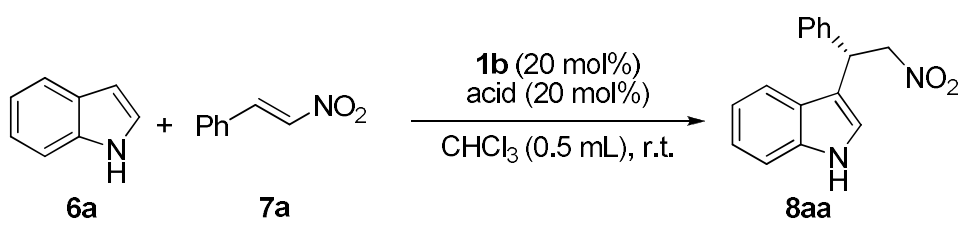<smiles>O=C(O)[C@H](O)c1ccccc1</smiles>

(R)-9a $85 \%$ yield $55 \%$ ee<smiles>CO[C](C(=O)O)c1ccccc1</smiles>

$( \pm)-9 d$ $90 \%$ yield $55 \%$ ee<smiles>O=C(O)[C@H](O)c1ccccc1</smiles>

(S)-9a

$90 \%$ yield $55 \%$ ee<smiles>O=C(O)COc1cccc2ccccc12</smiles>

\section{$9 e$} $46 \%$ yield $42 \%$ ee<smiles>O=C(O)Cc1ccccc1</smiles>

$9 \mathrm{~b}$

$83 \%$ yield $48 \%$ ee<smiles>CC(=O)O</smiles>

$9 f$ $60 \%$ yield $46 \%$ ee<smiles>CO[C@](C(=O)O)(c1ccccc1)C(F)(F)F</smiles>

(S)-9c

$90 \%$ yield $56 \%$ ee<smiles>C[C@H](O)C(=O)O</smiles>

(S)-9g

$64 \%$ yield $55 \%$ ee

Scheme 2. Screening of acids using urea catalyst $\mathbf{1 b}$.

Table 2. Effect of temperature of model reaction. ${ }^{a}$

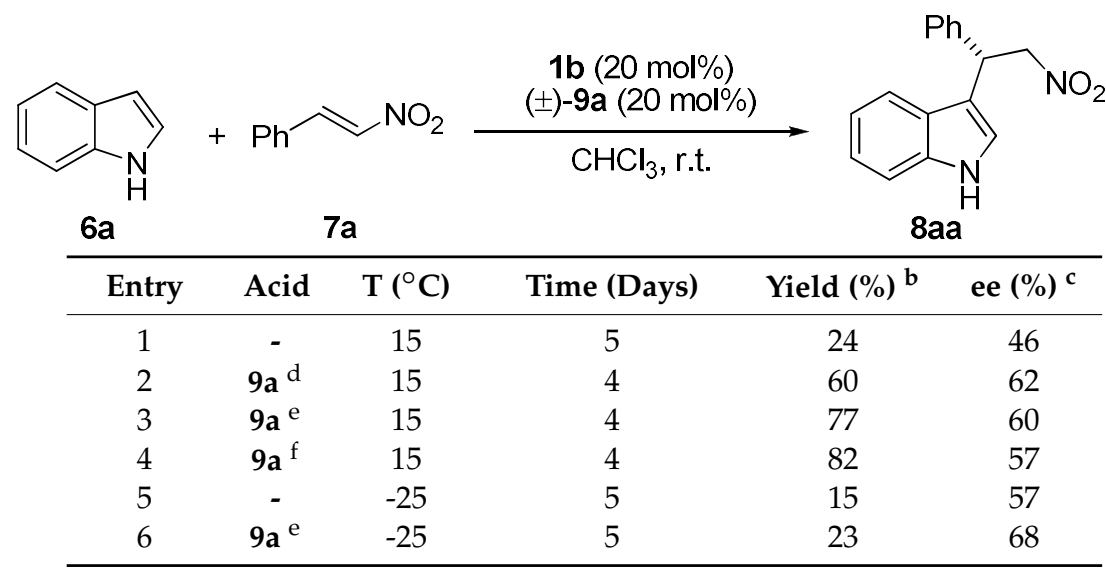

a To a mixture of catalyst $\mathbf{1 b}(20 \mathrm{~mol} \%, 0.02 \mathrm{mmol}),( \pm)$-mandelic acid $9 \mathbf{a}(20 \mathrm{~mol} \%, 0.02 \mathrm{mmol})$, and nitroalkene $7 \mathrm{a}(0.1 \mathrm{mmol})$ at 15 or $-25^{\circ} \mathrm{C}$, indole $6 \mathbf{a}(0.15 \mathrm{mmol})$ was added; ${ }^{\mathrm{b}}$ After isolation by column chromatography;

${ }^{\mathrm{c}}$ Determined by chiral HPLC analysis (Chiralpak IA, Hex:iPrOH 90:10, $\left.1 \mathrm{ml} / \mathrm{min}\right){ }^{\mathrm{d}} 2$ equiv. of acid (0.04 mmol);

e 3 equiv. of acid $(0.06 \mathrm{mmol}) ;{ }^{\mathrm{f}} 4$ equiv. of acid $(0.08 \mathrm{mmol})$.

The results demonstrated that the effect of Brønsted acid on the urea-based catalysis is maintained even at lower temperatures $\left(15\right.$ and $\left.-25{ }^{\circ} \mathrm{C}\right)$, although a gradual drop in the reaction yield was observed. On the other hand, it seems that the effect of the external Brønsted acid decreases at a lower temperature, where presumably the formation of urea aggregates prevails and increases the insolubility of the acid.

At this point, and since our goal was to test this alternative approach to improve the efficiency of the urea catalyst, we explored the substrate scope at room temperature (Scheme 3). 

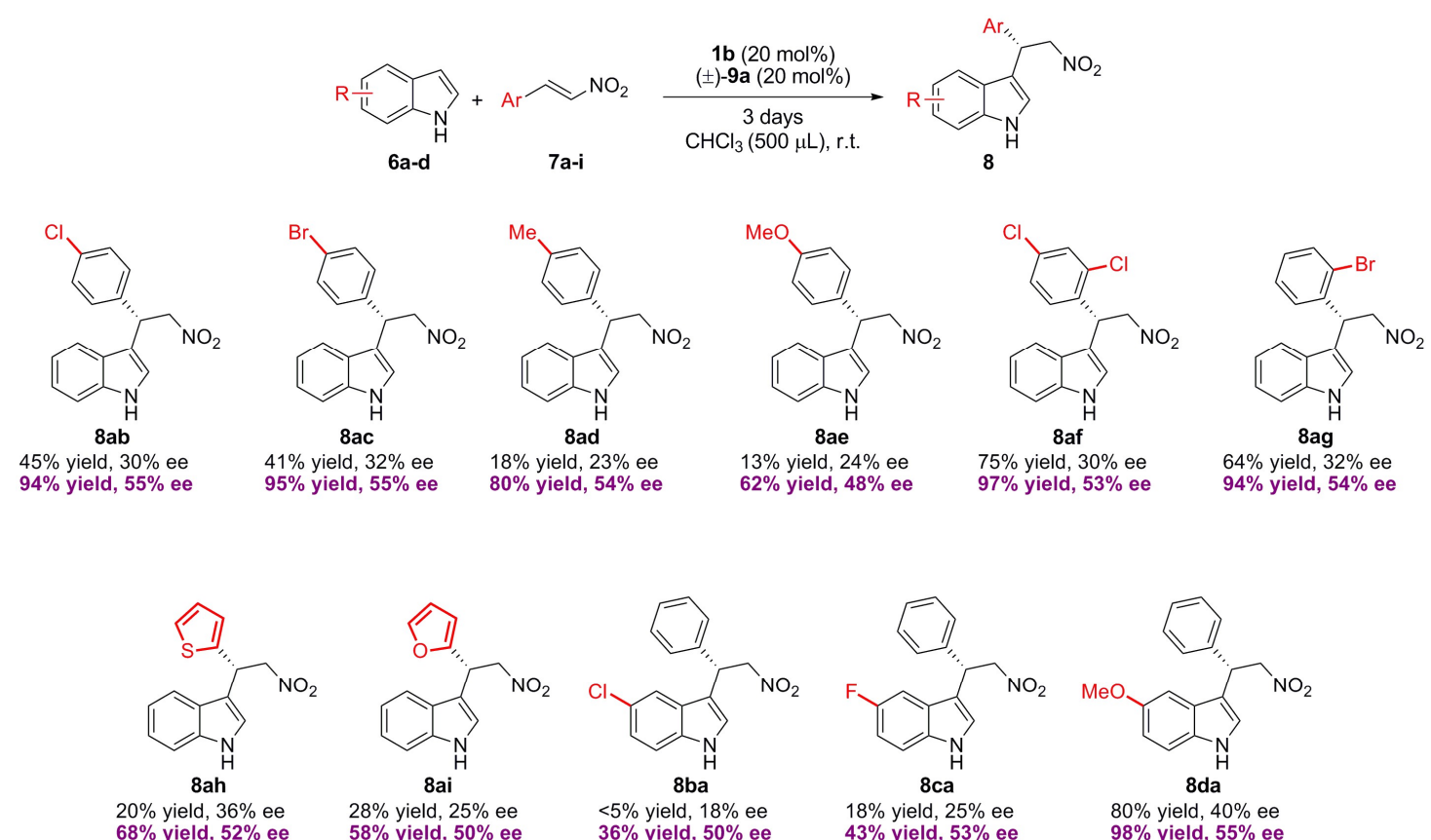

$18 \%$ yield, $25 \%$ ee

$80 \%$ yield, $40 \%$ ee

Scheme 3. Scope of the Friedel-Crafts alkylation reaction. The purple values are obtained in the presence of $\mathbf{1 b} \cdot( \pm)-\mathbf{9 a}$ and the black values are obtained in the absence of acid $( \pm)-\mathbf{9 a}$. The yields are obtained after isolation by column chromatography and the ee is determined by chiral HPLC analysis.

In order to compare the results obtained with $\mathbf{1 b} \cdot \mathbf{H A}$ and the sole catalyst $\mathbf{1 b}$, the reactions were stopped after three days. The results shown in Scheme 3 indicate that the working hypothesis was valid using different substituted nitroalkenes $\mathbf{7 a}-\mathbf{i}$ and indoles $\mathbf{6 a - d}$, affording the corresponding adducts $\mathbf{8}$ with higher yields and enantioselectivities compared to reactions in the absence of an external acid. The absolute configuration of adducts $\mathbf{8}$ was assigned by comparison of their optical rotation with those reported in the literature for the same compounds.

\subsection{Effect of Brønsted Acid on Urea Aggregation and Mechanistic Hypothesis}

The foregoing results suggest two important facts to be considered when adding an external acid to the reaction medium: first, the plausible rupture of self-assembled ureas by the acid; and second, the activation of the "free" urea through coordination by the acid. The fragmentation of urea aggregates, affording a higher concentration of "free" urea (or smaller soluble aggregates) in solution, could explain the enhancement of the reaction yield, but not necessarily an increase of the ee. However, a concurrent activation of the urea with the disassembly process could positively influence both the yield and the enantioselectivity of the process, as shown in Scheme 2.

With this in mind and in order to gain additional insight on the coordination mode between the Brønsted acid and the urea, we tested some additional key catalysts and additives (Table 3). 
Table 3. Effect of the nature of the catalytic complex. ${ }^{\text {a }}$
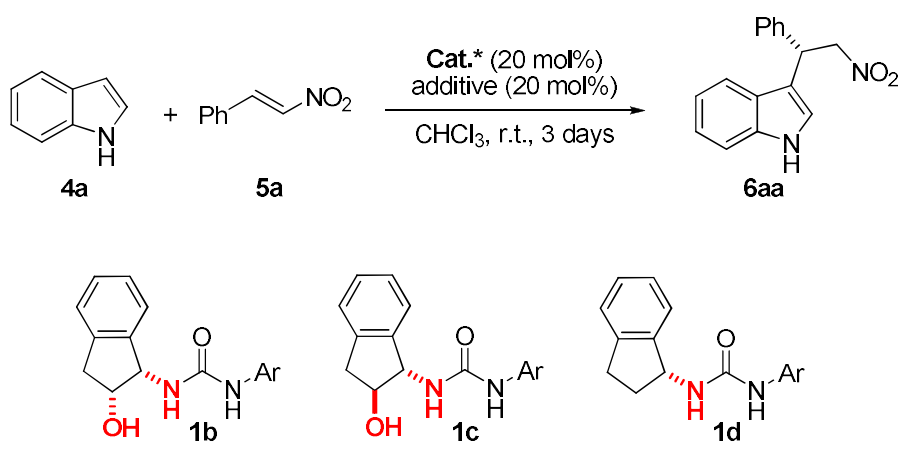

$\operatorname{Ar}: 3,5-\left(\mathrm{F}_{3} \mathrm{C}\right) \mathrm{C}_{6} \mathrm{H}_{3}$

\begin{tabular}{|c|c|c|c|c|}
\hline Entry & Catalyst & Acid & Yield (\%) ${ }^{b}$ & ee $(\%)^{c}$ \\
\hline 1 & $\mathbf{1 b}$ & - & 46 & 36 \\
\hline 2 & $1 b$ & $( \pm)-9 a$ & 88 & 55 \\
\hline 3 & $\mathbf{1 b}$ & & 83 & 48 \\
\hline 4 & $1 b$ & & 57 & 40 \\
\hline \multirow[t]{2}{*}{5} & $1 b$ & & 55 & 37 \\
\hline & & $( \pm)-9 i$ & & \\
\hline 6 & $1 b$ & $\mathrm{MeOH}$ & 68 & 40 \\
\hline 7 & 1c & $( \pm)-9 a$ & $18(13)^{d}$ & Rac. (Rac.) ${ }^{d}$ \\
\hline 8 & 1d & $( \pm)-9 a$ & $25(7)^{d}$ & Rac. (Rac.) ${ }^{d}$ \\
\hline
\end{tabular}

${ }^{\mathrm{a}}$ Unless specified, see Experimental Section; ${ }^{\mathrm{b}}$ After isolation by column chromatography; ${ }^{\mathrm{c}}$ Determined by chiral HPLC analysis (Chiralpak IA, Hex:iPrOH 90:10, $1 \mathrm{ml} / \mathrm{min}$ ); ${ }^{\mathrm{d}}$ values in parenthesis have been obtained in the absence of acid.

Additional important aspects can also be concluded from the results disclosed in Table 3. For instance, the presence of an $\mathrm{OH}$ group in the skeleton of $\mathbf{1} \mathbf{b}$ with cis configuration seems to be crucial for both the enantioselectivity and the reactivity of the process (compare entry 2 against entries 7 and 8), which is in good agreement with our previous observations with thioureas [45]. When additives $9 \mathbf{h}, 9 \mathbf{i}$ or $\mathrm{MeOH}$ were used (entries 4-6), the results were similar to those obtained with urea $\mathbf{1 b}$ alone (entry 1 ) in terms of selectivity, although a slightly better yield was obtained with the additives. This supports the scenario in which the additive could break urea interactions, generating more "free" urea, although in the absence of an additional activation, since only the $\mathrm{OH}$ of the carboxylic acid seems to be responsible for the activation of the urea catalyst. The effect observed with catalysts $\mathbf{1 c}$ and $\mathbf{1 d}$ was only evident in the reactivity of the process, since both catalysts alone afforded racemic products (entries 7 and 8 ). With these results, we were also able to discard the possible mode of activation in which both urea and acid simultaneously activate nitrostyrene, as previously proposed by other authors [79], since in this case the yield should be higher than that achieved with the use of acid $( \pm$ )-9a alone (Scheme 1,30\%).

Next, we analyzed the effect on both ee and reaction yield using progressive amounts of $( \pm)-9 \mathrm{a}$ with respect to urea $\mathbf{1 b}(0.02 \mathbf{~ m m o l})$ (Figure 4$)$. 


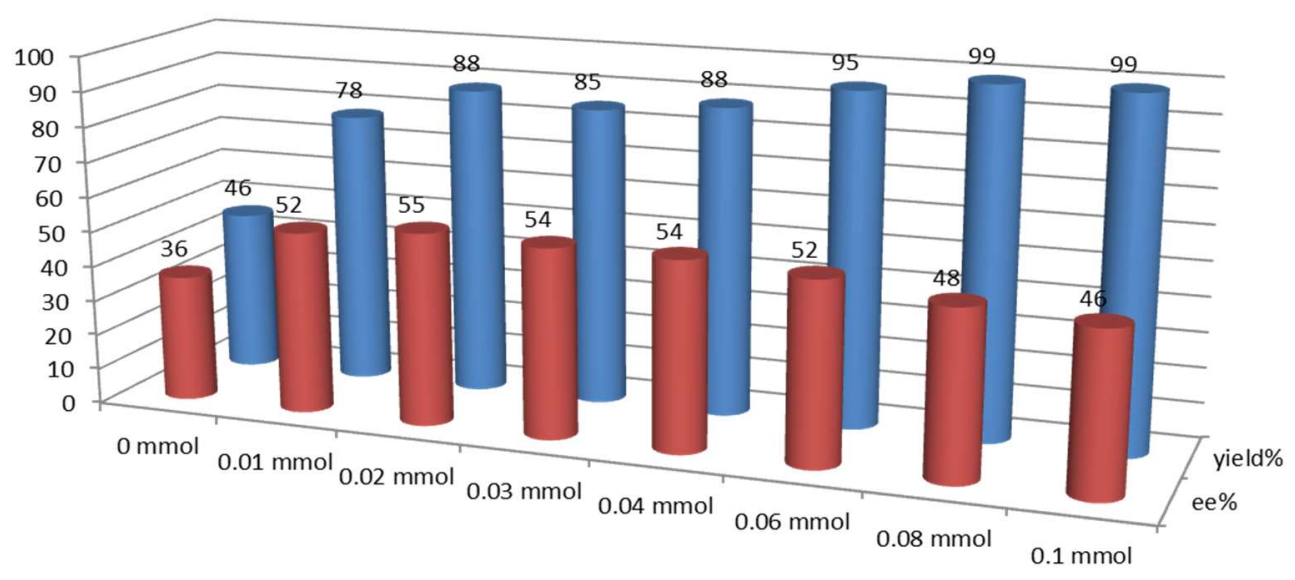

Figure 4. Effect of the addition of acid ( \pm )-9a using $20 \mathrm{~mol} \%$ of urea $\mathbf{1 b}$.

The results indicated that ca. $20-40 \mathrm{~mol} \%$ of acid is optimal for the activation effect. Higher amounts of acid further increased the yield, but caused a slightly decrease in the ee of the product, because the activation of the reaction through the acid alone could also take place, giving rise to a racemic product.

Since NMR techniques can provide important information on self-assembly processes in solution and in order to support the fragmentation of urea aggregates in the presence of acid, different ${ }^{1} \mathrm{H}-\mathrm{NMR}$ experiments were performed. We thus studied the variation in the signals of the urea catalyst $\mathbf{1 b}$ after progressive addition of acid ( \pm )-9a in $\mathrm{CDCl}_{3}$ (Table 4 and Figures S1-S8).

Table 4. Effect of the acid on the ${ }^{1} \mathrm{H}$ NMR signals of the urea catalyst. ${ }^{\text {a }}$

\begin{tabular}{|c|c|c|c|c|c|c|c|}
\hline Entry & $\begin{array}{c}( \pm)-9 \mathrm{a} \\
(\mathrm{mmol})\end{array}$ & $\begin{array}{l}\delta \mathrm{NH}_{\mathrm{a}} \\
(\mathrm{ppm})\end{array}$ & $\begin{array}{c}\delta H_{b} \\
(\mathrm{ppm})\end{array}$ & $\begin{array}{c}\delta \mathrm{H}_{\mathrm{c}} \\
(\mathrm{ppm})\end{array}$ & $\begin{array}{c}\delta \mathrm{H}_{\mathrm{d}} \\
(\mathrm{ppm})\end{array}$ & $\begin{array}{c}\delta \mathrm{H}_{\mathrm{d}^{\prime}} \\
(\mathrm{ppm})\end{array}$ & $\begin{array}{l}\text { Ratio Integrals } \\
\text { Urea:Standard }\end{array}$ \\
\hline 1 & 0 & 7.937 & 5.553 & 4.691 & 3.238 & 2.976 & $0.22: 1$ \\
\hline 2 & 0.01 & 7.888 & 5.818 & 4.670 & 3.219 & 2.949 & $0.37: 1$ \\
\hline 3 & 0.02 & 7.852 & 5.971 & 4.635 & 3.177 & 2.923 & $0.62: 1$ \\
\hline 4 & 0.03 & 7.852 & 6.030 & 4.629 & 3.173 & 2.926 & $0.70: 1$ \\
\hline 5 & 0.04 & 7.844 & 6.032 & 4.630 & 3.176 & 2.923 & 0.79:1 \\
\hline 6 & 0.06 & 7.845 & 6.034 & 4.625 & 3.167 & 2.920 & $0.78: 1$ \\
\hline 7 & 0.08 & 7.770 & 5.960 & 4.554 & 3.093 & 2.820 & $0.82: 1$ \\
\hline 8 & 0.1 & 7.844 & 6.035 & 4.631 & 3.169 & 2.920 & $0.88: 1$ \\
\hline
\end{tabular}

a To a solution of urea $\mathbf{1 b}(0.02 \mathrm{mmol})$ in $\mathrm{CDCl}_{3}(0.5 \mathrm{~mL})$ and mesitylene $(0.0075 \mathrm{mmol})$, as internal standard, acid $( \pm)-9 \mathrm{a}$ is added after each measure of ${ }^{1} \mathrm{H}$ NMR.

Among these NMR spectra, we only observed one species of the urea due to the fact that the chemical exchange between the self-assembled and non-self-assembled species is rapid on the NMR timescale. Additionally, with the addition of acid, urea signals show sharper peaks in comparison with broader peaks found when it is mainly aggregated (see supporting information Figure S1-S8). This is because when urea is aggregated, the major part of the signals belongs to the NMR-silent (entry 1, ratio integrals ureas:standard) [80]. In contrast, when urea self-association is progressively broken with the addition of acid, the integrals of the urea increase in relation to the standard (ratio integrals ureas:standard). It was also observed that the $\mathrm{NH}_{\mathrm{a}}$ signal of urea for a given concentration $(0.02 \mathrm{mmol} / 0.5 \mathrm{~mL} \mathrm{CHCl} 3)$, when the equilibrium is shifted in favor of the aggregates 
(entry 1), is sensitive to the presence of acid and is progressively highfield shifted with the addition of acid. This is in agreement with observations made by other authors in different self-assembly systems $[81,82]$. These facts could relate to the presence of more free molecules of urea or smaller aggregates in solution and, therefore, support the disruption of urea self-assembly with the presence of acid. Other signals of the urea are also affected by the presence of acid, as shown in Table 4 . When 5 equivalents of acid are added (entry 8), the signals of the urea catalysts move in the opposite direction (to downfield). This could be in agreement with the equilibrium shifted to a predominant activation of the urea molecules, and therefore, with the ensuing acidification of the signals. A major variation in urea signals is observed with the addition of $0.02 \mathrm{mmol}$ of acid, as in the catalytic reactions, a plateau is more or less reached after that, and increasing the amount of acid does not strongly affect the shifting of the signals. A DOSY NMR experiment [83-85] also supports the coordination of the acid to the urea, since it is possible to find two different aggregate species in a given sample (urea-acid $0.02 \mathrm{mmol}: 0.02 \mathrm{mmol}$ ): the urea self-assembled and the urea acid complex (Figure 5).

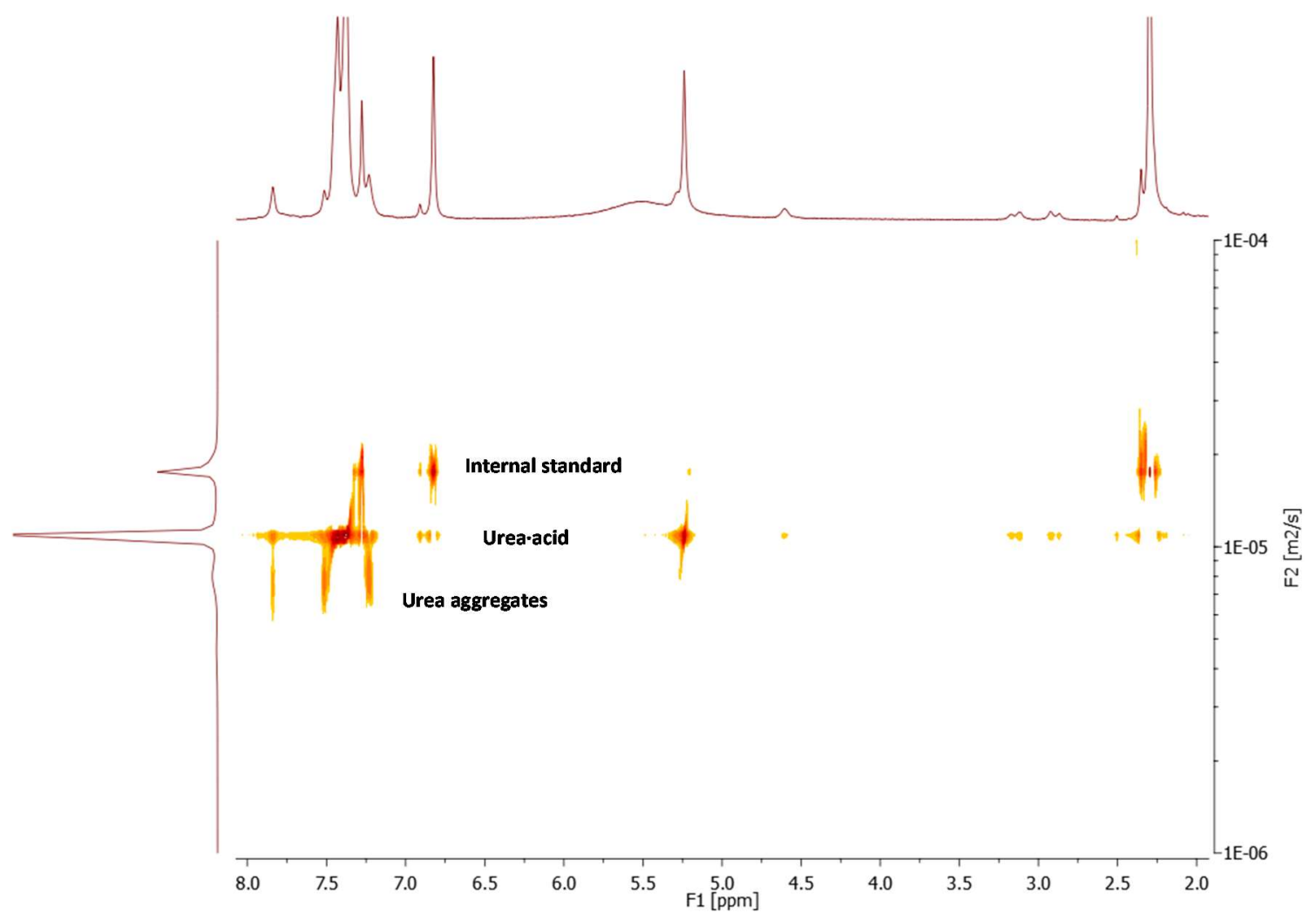

Figure 5. DOSY NMR experiment in $\mathrm{CDCl}_{3}(300 \mathrm{MHz})$.

We also performed a mass spectrum of the mixture urea $\mathbf{1} \mathbf{b} \cdot \mathbf{a c i d}( \pm)-\mathbf{9 a}(0.02 \mathrm{mmol}: 0.02 \mathrm{mmol})$ in $0.5 \mathrm{~mL}$ of $\mathrm{CHCl}_{3}$ (Figure 6), since ESI-MS has been incorporated as an important technique for mechanistic studies of organic reactions [86]. In the cationic ESI spectra obtained directly from solution to the gas phase, we found different species, and among them the remarkable mass peak of the active complex proposed in this manuscript (catalyst $\mathbf{1 b}+$ mandelic acid $( \pm)-9 a)(M+K=595.1)$. Other superior species related to the previous one have also been found in the mixture. Interestingly, we could not observe mass from the union of two or more ureas, although we cannot discard the presence of this complex in the mixture of reaction. It could be due to the impact of this technique that they split into free molecules of urea. 


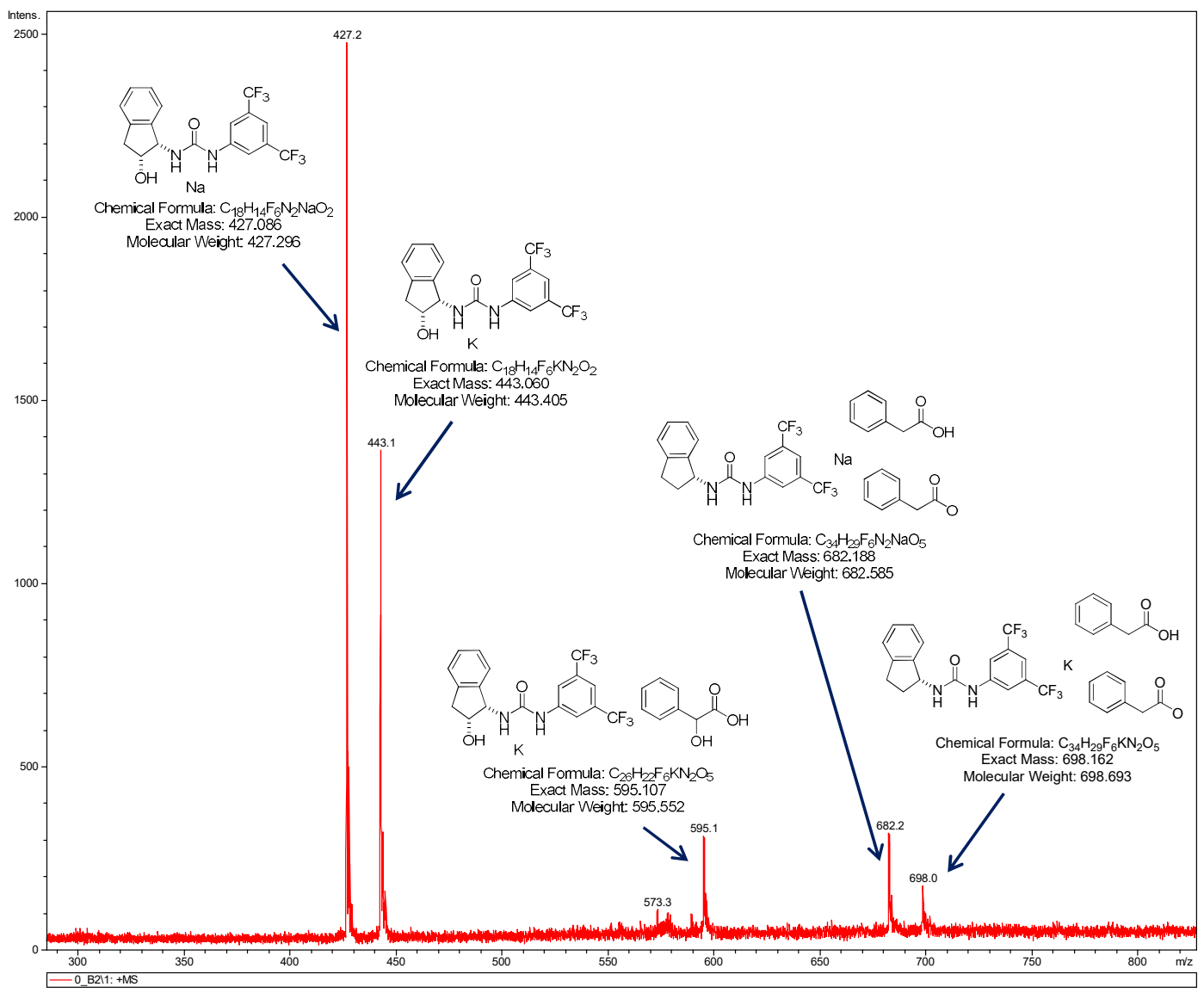

Figure 6. Cationic ESI-MS spectra experiment in $\mathrm{CHCl}_{3}$.

Based on these evidences and the results of our previous investigations [45,46], TSI is proposed as the plausible mode of activation between Brønsted acid, urea $\mathbf{1} \mathbf{b}$ and the reagents (Figure 7).

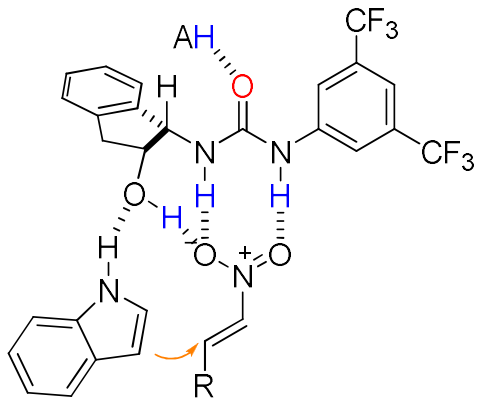

TSI

Figure 7. Proposed transition states for the [urea-acid]-catalyzed Friedel-Crafts reaction.

1b.HA complex could be identified as the most reactive species due to the increased acidity of $\mathrm{NH}$ in urea $\mathbf{1 b}$ after synergic coordination with Brønsted acid. Furthermore, improvement in enantioselectivity could be attributed to the formation of a more rigid assembly (on combination of both structures after breaking urea self-association) in the transition state. This mode of activation supports the fact that the observed enantiomer is a result of the chirality of the organocatalyst used. Further computational calculations could shed light on this singular mode of activation. 


\subsection{Effect of Brønsted Acids on the Stability of Urea Aggregates}

When the reaction was performed in $\mathrm{CH}_{2} \mathrm{Cl}_{2}$ or $\mathrm{CHCl}_{3}$ using urea $\mathbf{1 b}$ alone, the formation of dense gel-like aggregates was observed, which was in agreement with our previous studies about the self-assembly behavior of these ureas in solution [47]. The viscosity of the mixture was visually decreased upon the addition of acid $9 \mathbf{a}$, which could theoretically be in agreement with a weakening of the self-assembled network, spontaneously generated by the urea catalyst and, hence, with our mechanistic assumptions from the catalytic experiments. This hypothesis was demonstrated by analyzing the thermal stability, flow properties and morphological features of the supramolecular gel made of urea $\mathbf{1 b}$ in the absence or presence of various acid additives at different molar ratios urea 1 b:acid (i.e. 0.1, 0.3, 0.9). Two solvents (i.e. chloroform-solvent used in the reactions-and toluene) were used in this study for comparative purposes. In general, gels were transparent in appearance, although some systems prepared in chloroform were slightly translucent (Figure 8). Most studies in this section were conducted with gels prepared within approximately $30 \mathrm{~min}$ of the corresponding critical gelation concentrations (CGC) of $\mathbf{1 b}$, which were previously established in $7 \mathrm{~g} / \mathrm{L}$ (chloroform) and $3 \mathrm{~g} / \mathrm{L}$ (toluene) [47]. The detrimental effect of the acid additives was considerably more evident for the gels in chloroform than in toluene. Therefore, and for the sake of clarity, the most relevant data refereed to the gels in chloroform are included in this section, whereas most data derived from the systems in toluene are provided in Supporting Information (Table S1). The first sign of the weakening effect that the acid additive has on the physical gel network formed by self-assembled urea molecules was a partial gel-to-sol phase transition, visible to the naked eye (Figure 8B-E). In general, the amount of expelled fluid usually increased with increasing amounts of acid.
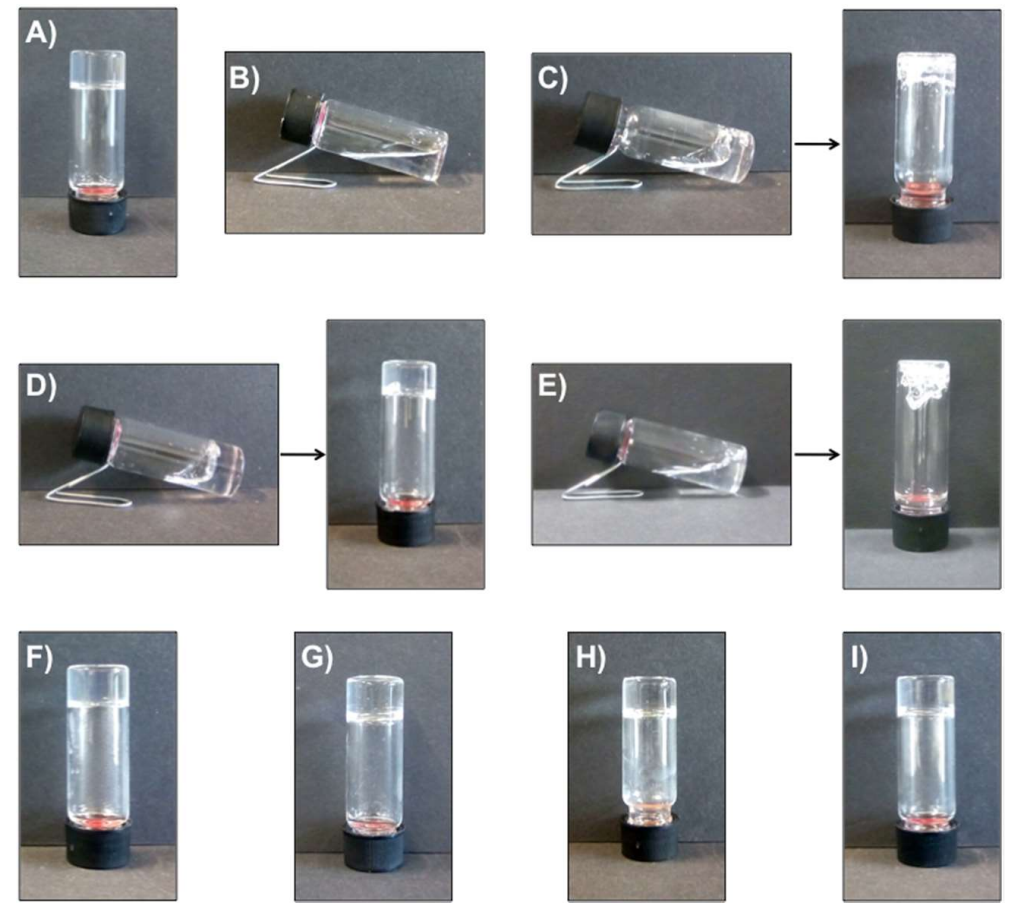

Figure 8. Representative photographs of undoped gels and gels doped with different additives under different conditions: (A) Undoped gel made of $\mathbf{1 b}$ in $\mathrm{CHCl}_{3}(c=7 \mathrm{~g} / \mathrm{L} ; 1 \mathrm{~mL}) ;(\mathbf{B}-\mathbf{D})$ doped gels made of $\mathbf{1 b}$ in $\mathrm{CHCl}_{3}(c=7 \mathrm{~g} / \mathrm{L} ; 1 \mathrm{~mL})$ and mandelic acid at different molar ratios $\mathbf{1 b}$ :acid: (B) 0.9, (C) 0.3, (D) 0.1; (E) doped gel made of $\mathbf{1 b}$ in $\mathrm{CHCl}_{3}(c=7 \mathrm{~g} / \mathrm{L} ; 1 \mathrm{~mL}$ ) and benzoic acid (molar ratios $\mathbf{1 b}$ :acid = 0.9); (F) doped gel made of $\mathbf{1 b}$ in $\mathrm{CHCl}_{3}(c=7 \mathrm{~g} / \mathrm{L} ; 1 \mathrm{~mL}$ ) and acetic acid (molar ratio $1 \mathbf{b}$ :acid $=0.9) ;(\mathbf{G})$ undoped gel made of $\mathbf{1 b}$ in toluene ( $c=3 \mathrm{~g} / \mathrm{L} ; 1 \mathrm{~mL}) ;(\mathbf{H})$ doped gel made of $\mathbf{1 b}$ in toluene $(c=3 \mathrm{~g} / \mathrm{L} ; 1 \mathrm{~mL})$ and mandelic acid (molar ratio $\mathbf{1 b}$ :acid $=0.9)$; $(\mathbf{I})$ doped gel made of $\mathbf{1 b}$ in toluene $(c=3 \mathrm{~g} / \mathrm{L} ; 1 \mathrm{~mL}$ ) and acetic acid (molar ratio $\mathbf{1 b}$ :acid $=0.9)$. 
This was also accompanied by a gradual decrease of the $T_{\text {gel }}$ of the remaining gel phase (Figure 9 and Table S1) in comparison with the $T_{\text {gel }}$ of the pristine gel made of $\mathbf{1 b}$ alone $\left(\sim 60^{\circ} \mathrm{C}\right)$. A preliminary design of experiments with chiral Brønsted acids (e.g. mandelic acid) showed no significant differences on the above-mentioned effects when using either the racemic mixture of any of the corresponding enantiomers (Table S1). Moreover, gelation kinetics of the doped gels was also notably reduced to several hours in most cases, compared to pristine gels (Table S1).

In terms of the effect of different acids, the most remarkable outcome was observed with mandelic acid, which prevented gelation at molar ratio $(\mathbf{1} \mathbf{b}$ :acid $)=0.9$. Taking experiments with mandelic acid and benzoic acid as representative examples, molar ratios (1 $\mathbf{b}$ :acid) of 0.6 and 0.9 gave similar results (Table S1). Moreover, experiments using the corresponding methyl ester caused minor disruption in the gel, suggesting the critical role of the free carboxylic group in the disassembly of the supramolecular aggregates. These results are in good agreement with the favorable effect observed in reactions using $\mathbf{1 b}$ and mandelic acid in equimolar amounts. In general, other acids such as acetic, phenylacetic, benzoic and lactic acids also caused destabilization of the gel network, albeit to a lesser extent. The results suggest that the acidity of the carboxylic group (e.g., mandelic acid is the most acidic among these examples) might play a more important role than structural features.

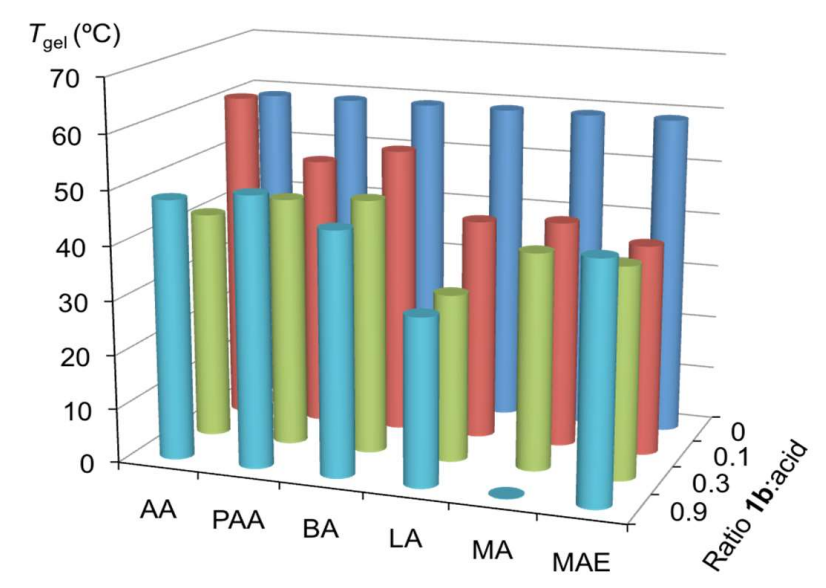

Figure 9. $T_{\text {gel }}$ of the gel made of $\mathbf{1 b}(c=7 \mathrm{~g} / \mathrm{L})$ in $\mathrm{CHCl}_{3}$ and the effect caused by the incorporation of selected acids at different ratios (molar ratio 1b:acid $=0.1,0.3,0.9$ ). Abbreviations: $\mathrm{AA}=$ acetic acid; $\mathrm{PAA}=$ phenylacetic acid; $\mathrm{BA}=$ benzoic acid; $\mathrm{LA}=$ lactic acid; $\mathrm{MA}=$ mandelic acid; $\mathrm{MAE}=$ mandelic acid methyl ester. The average values of at least two independent measurements are shown. Estimated error $\pm 2{ }^{\circ} \mathrm{C}$.

The decrease in thermostability of supramolecular urea aggregates upon incorporation of the acid was also accompanied by a detriment of their mechanical properties, as evidenced by oscillatory rheological measurements of selected gels prepared in the absence and presence of the acid. For instance, dynamic frequency sweep (DFS) measurements of gels based on $\mathbf{1 b}$ in chloroform showed that the incorporation of small amounts of mandelic acid (i.e. molar ratio $\mathbf{1 b}$ :acid $=0.1$ ) caused a drop in the storage modulus $G^{\prime}$ of $\sim 1.8$ times compared to the undoped gel (i.e. $G^{\prime}$ (undoped) $\sim 30493$ Pa vs. $G^{\prime}$ (doped) 17096 Pa) (Figure 10A). In addition, the loss factor or tan $\delta$, which represents mechanical damping or internal friction of the viscoelastic system, increased from $\sim 0.180$ (undoped) to $\sim 0.239$ (doped). This indicates that the material becomes more dissipative in the presence of the acid. Both undoped and doped gels were very brittle in nature, as shown by dynamic strain sweep (DSS) measurements (i.e. gel-to-sol transition occurred between $9-10 \%$ strain for all samples) (Figure 10B). Dynamic time sweep (DTS) plots showing constant moduli values over time within the linear regime are provided in Supporting Information (Figure S45A). In concordance with the minor effect that acids showed on the thermostability of toluene gels, additional rheological experiments also showed a lower influence on the mechanical strength of the gels prepared in toluene (Figure S45B-D). 

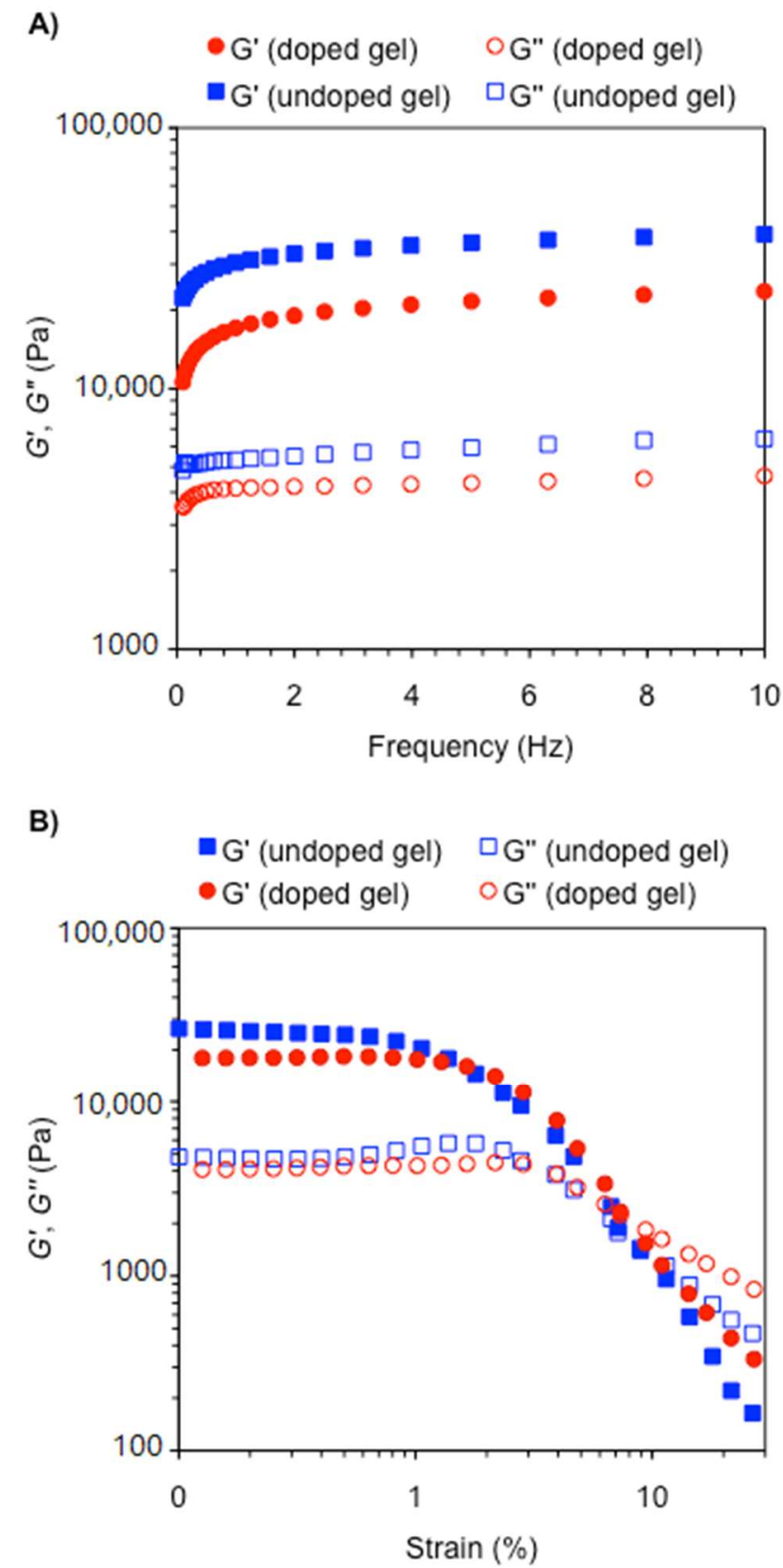

Figure 10. (A) DFS and (B) DSS measurements of undoped gel made of $\mathbf{1 b}$ in $\mathrm{CHCl}_{3}(\mathrm{c}=14 \mathrm{~g} / \mathrm{L})$, and doped gel made of $\mathbf{1 b}(\mathrm{c}=14 \mathrm{~g} / \mathrm{L})$ and mandelic acid (molar ratio $\mathbf{1 b}$ :acid $=0.1)$ in $\mathrm{CHCl}_{3}$.

Finally, the observed disrupting effect of the acids on the supramolecular aggregates of $\mathbf{1 b}$ could also be related to changes in the microstructure of the xerogels obtained by freeze-drying the corresponding gels. An entangled microfibrillar network over a dense and continuous structure was observed for updoped xerogels (Figure 11), whereas the incorporation of $10 \mathrm{~mol} \%$ of mandelic acid (with respect to $\mathbf{1 b}$ ) induced the formation of laminar and smoother structures (Figure 11A vs. Figure 11B). The discontinuous appearance of the doped xerogel could explain a less-effective immobilization of solvent molecules, which is in agreement with the observed lower $T_{\text {gel }}$ and mechanical strength of the bulk material. In contrast, FE-SEM images of the corresponding xerogels showed little effect on the microstructure in comparison with the undoped network (Figure 11C vs. Figure 11D). It is worth mentioning that the harmful effect of acids on the stability of supramolecular gel networks was not exclusive to urea $\mathbf{1 b}$. 

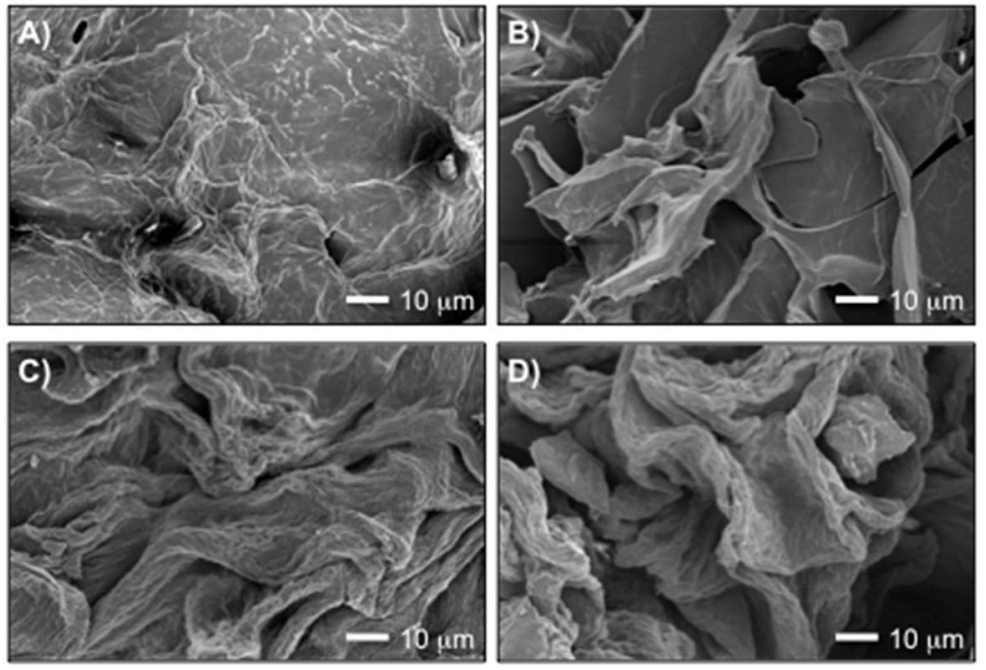

Figure 11. Representative FE-SEM images of xerogels derived from (A) pristine gel made of $\mathbf{1 b}$ $(c=7 \mathrm{~g} / \mathrm{L})$ in $\mathrm{CHCl}_{3},(\mathbf{B})$ doped gel made of $\mathbf{1 b}(c=7 \mathrm{~g} / \mathrm{L})$ and mandelic acid (molar ratio $\mathbf{1 b}$ :acid $\left.=0.1\right)$ in $\mathrm{CHCl}_{3},(\mathbf{C})$ pristine gel made of $\mathbf{1 b}(c=3 \mathrm{~g} / \mathrm{L})$ in toluene, (D) doped gel made of $\mathbf{1 b}(c=3 \mathrm{~g} / \mathrm{L})$ and mandelic acid (molar ratio $\mathbf{1 b}$ :acid $=0.1$ ) in toluene.

\section{Materials and Methods}

\subsection{Experimental Details}

All commercially available solvents and reagents were used as received. $\mathrm{CHCl}_{3}$ was filtered through basic alumina prior to use to avoid the presence of trace amounts of acid. ${ }^{1} \mathrm{H}-\mathrm{NMR}$ spectra were recorded at $300 \mathrm{MHz} . \mathrm{CDCl}_{3}$ was used as a deuterated solvent. Chiral urea catalysts were obtained following literature procedures: $\mathbf{1 b}$ [47], 1c [47], 1d [47] and 1e [87]. ${ }^{1} \mathrm{H}$ and ${ }^{13} \mathrm{C} \mathrm{NMR} \mathrm{spectra}$ for compounds 8aa [43], 8ab [88], 8ac [88], 8ad [88], 8ae [88], 8af [89], 8ag [90], 8ah [88], 8ai [88], $\mathbf{8 b a}$ [43], 8ca [47] and $\mathbf{8 b a}$ [53] are consistent with values previously reported in the literature.

\subsection{General Procedure for the $\mathbf{1 b} \cdot \mathbf{H A}$-Catalyzed Friedel-Crafts Alkylation Reaction}

To a mixture of urea $\mathbf{1 b}(20 \mathrm{~mol} \%),( \pm)$-mandelic acid $9 \mathbf{a}(20 \mathrm{~mol} \%)$, and nitroalkene $7 \mathbf{a}-\mathbf{i}$ $(0.1 \mathrm{mmol})$ at $25^{\circ} \mathrm{C}$ in a test tube $\mathrm{CHCl}_{3}$ (filtered through basic alumina, $0.5 \mathrm{~mL}$ ) was added and then indole $6 \mathbf{a}-\mathbf{d}(0.15 \mathrm{mmol})$. After 3 days, the residue was purified by liquid chromatography $\left(\mathrm{SiO}_{2}\right.$; hexane/EtOAc, 8:2) to obtain the desired adducts 8. Yields and enantioselectivities are reported in Scheme 3. Spectral and analytical data for compounds 8 are in agreement with those previously reported in the literature.

(S)-3-(2-Nitro-1-phenylethyl)-1H-indole (8aa) [43]. Following the general procedure, compound 8 aa was obtained after 3 days of reaction at room temperature in $88 \%$ yield. The ee of the product was determined to be $55 \%$ by HPLC using a Daicel Chiralpak IA column $(n$-hexane $/ i-\mathrm{PrOH}=90: 10$, flow rate $\left.1 \mathrm{~mL} \cdot \mathrm{min}^{-1}, \lambda=254.0 \mathrm{~nm}\right): \tau_{\text {major }}=15.3 \mathrm{~min} ; \tau_{\text {minor }}=14.0 \mathrm{~min} .[\alpha]_{\mathrm{D}}{ }^{24}=+10.7\left(c 0.40, \mathrm{CH}_{2} \mathrm{Cl}_{2}\right.$, $55 \%$ ee) $\left\{\right.$ lit. [53], $[\alpha]_{\mathrm{D}}{ }^{24}+25.3\left(c 0.53, \mathrm{CH}_{2} \mathrm{Cl}_{2}\right)$ for $(S)-8 \mathbf{a a}, 88 \%$ ee $\}$.

(S)-3-(1-(4-Chlorophenyl)-2-nitroethyl)-1H-indole (8ab) [88]. Following the general procedure, compound $8 \mathbf{a b}$ was obtained after 3 days of reaction at room temperature in $94 \%$ yield. The ee of the product was determined to be $55 \%$ by HPLC using a Daicel Chiralpak IA column ( $n$-hexane $/ i-\mathrm{PrOH}=90: 10$, flow rate $1 \mathrm{~mL} \cdot \mathrm{min}^{-1}, \lambda=254.0 \mathrm{~nm}$ ): $\tau_{\text {major }}=20.2 \mathrm{~min} ; \tau_{\text {minor }}=16.8 \mathrm{~min}$. $[\alpha]_{\mathrm{D}}{ }^{24}=+1.5$ (c $0.53, \mathrm{CH}_{2} \mathrm{Cl}_{2}, 55 \%$ ee). \{lit. [88], $[\alpha]_{\mathrm{D}}{ }^{20}+7.5\left(c 1.2, \mathrm{CH}_{2} \mathrm{Cl}_{2}\right)$, for $(S)-8 \mathrm{ab}, 82 \%$ ee\}.

(S)-3-(1-(4-Bromophenyl)-2-nitroethyl)-1H-indole (8ac) [88]. Following the general procedure, compound 8ac was obtained after 3 days of reaction at room temperature in $95 \%$ yield. The ee of the product was determined to be $55 \%$ by HPLC using a Daicel Chiralpak IA column 
( $n$-hexane $/ i-\mathrm{PrOH}=90: 10$, flow rate $\left.1 \mathrm{~mL} \cdot \mathrm{min}^{-1}, \lambda=254.0 \mathrm{~nm}\right): \tau_{\text {major }}=21.2 \mathrm{~min} ; \tau_{\text {minor }}=17.6 \mathrm{~min}$. $[\alpha]_{\mathrm{D}}{ }^{24}=-4.2\left(c 0.47, \mathrm{CH}_{2} \mathrm{Cl}_{2}, 55 \% \text { ee) \{lit. [88], [ } \alpha\right]_{\mathrm{D}}{ }^{20}-1.7\left(c 1.0, \mathrm{CH}_{2} \mathrm{Cl}_{2}\right)$, for $(S)-8 \mathrm{ac}, 90 \%$ ee\}.

(S)-3-(2-Nitro-1-p-tolylethyl)-1H-indole (8ad) [88]. Following the general procedure, compound 8 ad was obtained after 3 days of reaction at room temperature in $80 \%$ yield. The ee of the product was determined to be $54 \%$ by HPLC using a Daicel Chiralpak IA column ( $n$-hexane $/ i$-PrOH $=90: 10$, flow rate $\left.1 \mathrm{~mL} \cdot \mathrm{min}^{-1}, \lambda=254.0 \mathrm{~nm}\right): \tau_{\text {major }}=14.4 \mathrm{~min} ; \tau_{\text {minor }}=13.0 \mathrm{~min} .[\alpha]_{\mathrm{D}}{ }^{25}=+5.1\left(c 0.43, \mathrm{CH}_{2} \mathrm{Cl}_{2}, 54 \%\right.$ ee) $\left\{\right.$ lit. $[88],[\alpha]_{\mathrm{D}}{ }^{20}+16.4\left(c 0.9, \mathrm{CH}_{2} \mathrm{Cl}_{2}\right)$, for $(S)-8 \mathrm{ad}, 81 \%$ ee\}.

(S)-3-(1-(4-methoxyphenyl)-2-nitroethyl-1H-indole (8ae) [88]. Following the general procedure, compound 8ae was obtained after 3 days of reaction at room temperature in $62 \%$ yield. The ee of the product was determined to be $48 \%$ by HPLC using a Daicel Chiralpak IB column ( $n$-hexane $/ i-\mathrm{PrOH}=80: 20$, flow rate $1 \mathrm{~mL} \cdot \mathrm{min}^{-1}, \lambda=254.0 \mathrm{~nm}$ ): $\tau_{\text {major }}=22.4 \mathrm{~min} ; \tau_{\text {minor }}=24.3 \mathrm{~min}$. $[\alpha]_{\mathrm{D}}^{25}=+14.4\left(c 0.19, \mathrm{CH}_{2} \mathrm{Cl}_{2}, 48 \%\right.$ ee) \{lit. [88], $[\alpha]_{\mathrm{D}}{ }^{20}+26.4\left(c 1.1, \mathrm{CH}_{2} \mathrm{Cl}_{2}\right)$, for $(S)-8 \mathbf{a e}, 81 \%$ ee\}.

(R)-3-(1-(2,4-dichlorophenyl)-2-nitroethyl)-1H-indole (8af) [89]. Following the general procedure, compound 8af was obtained after 3 days of reaction at room temperature in $97 \%$ yield. The ee of the product was determined to be $53 \%$ by HPLC using a Daicel Chiralpak IA column ( $n$-hexane $/ i-\mathrm{PrOH}=90: 10$, flow rate $\left.1 \mathrm{~mL} \cdot \mathrm{min}^{-1}, \lambda=254.0 \mathrm{~nm}\right): \tau_{\text {major }}=14.1 \mathrm{~min} ; \tau_{\text {minor }}=12.7 \mathrm{~min} .[\alpha]_{\mathrm{D}}{ }^{25}=+32.5\left(c 0.27, \mathrm{CH}_{2} \mathrm{Cl}_{2}\right.$, $53 \%$ ee).

(R)-3-(1-(2-Bromophenyl)-2-nitroethyl)-1H-indole (8ag) [90]. Following the general procedure, compound 8ag was obtained after 3 days of reaction at room temperature in $94 \%$ yield. The ee of the product was determined to be $54 \%$ by HPLC using a Daicel Chiralpak IB column $(n$-hexane $/ i-\mathrm{PrOH}=80: 20$, flow rate $\left.1 \mathrm{~mL} \cdot \mathrm{min}^{-1}, \lambda=254.0 \mathrm{~nm}\right): \tau_{\text {major }}=26.7 \mathrm{~min} ; \tau_{\text {minor }}=18.4 \mathrm{~min} .[\alpha]_{\mathrm{D}}{ }^{25}=+56.4\left(c 0.20, \mathrm{CH}_{2} \mathrm{Cl}_{2}\right.$, $54 \%$ ee) $\left\{\right.$ lit. [90], $[\alpha]_{\mathrm{D}}^{22}-99.9\left(c 1.3, \mathrm{CH}_{2} \mathrm{Cl}_{2}\right)$, for (S)-8ag, $96 \%$ ee\}.

(S)-3-(2-nitro-1-(thiophen-2-yl)ethyl)-1H-indole (8ah) [88]. Following the general procedure, compound 8ah was obtained after 3 days of reaction at room temperature in $68 \%$ yield. The ee of the product was determined to be $52 \%$ by HPLC using a Daicel Chiralpak IA column ( $n$-hexane $/ i-\mathrm{PrOH}=90: 10$, flow rate $1 \mathrm{~mL} \cdot \mathrm{min}^{-1}, \lambda=254.0 \mathrm{~nm}$ ): $\tau_{\text {major }}=19.1 \mathrm{~min} ; \tau_{\text {minor }}=17.2 \mathrm{~min}$. $[\alpha]_{\mathrm{D}}^{24}=+10.6\left(c 0.46, \mathrm{CH}_{2} \mathrm{Cl}_{2}, 52 \%\right.$ ee) \{lit. [88], $[\alpha]_{\mathrm{D}}{ }^{20}+24.3\left(c 1.0, \mathrm{CH}_{2} \mathrm{Cl}_{2}\right)$, for $(S)-8 \mathrm{ah}, 82 \%$ ee $\}$.

(S)-3-(1-(furan-2-yl)-2-nitroethyl)-1H-indole (8ai) [88]. Following the general procedure, compound 8ai was obtained after 3 days of reaction at room temperature in $58 \%$ yield. The ee of the product was determined to be $50 \%$ by HPLC using a Daicel Chiralpak IB column ( $n$-hexane $/ i-\mathrm{PrOH}=80: 20$, flow rate $\left.1 \mathrm{~mL} \cdot \mathrm{min}^{-1}, \lambda=254.0 \mathrm{~nm}\right): \tau_{\text {major }}=16.7 \mathrm{~min}$; $\tau_{\text {minor }}=12.6 \mathrm{~min} .[\alpha]_{\mathrm{D}}{ }^{25}=-16.4\left(\right.$ c $1.24, \mathrm{CH}_{2} \mathrm{Cl}_{2}, 50 \%$ ee $)$ \{lit. [88], $[\alpha]_{\mathrm{D}}{ }^{20}-78\left(c 1.0, \mathrm{CH}_{2} \mathrm{Cl}_{2}\right.$, for $(S)-8 \mathrm{ai}, 78 \%$ ee\}.

(S)-5-chloro-3-(2-nitro-1-phenylethyl)-1H-indole (8ba) [43]. Following the general procedure, compound 8 ba was obtained after 3 days of reaction at room temperature in $36 \%$ yield. The ee of the product was determined to be $50 \%$ by HPLC using a Daicel Chiralpak IA column ( $n$-hexane $/ i-\mathrm{PrOH}=90: 10$, flow rate $1 \mathrm{~mL} \cdot \mathrm{min}^{-1}, \lambda=254.0 \mathrm{~nm}$ ): $\tau_{\text {major }}=13.3 \mathrm{~min} ; \tau_{\text {minor }}=12.1 \mathrm{~min}$. $[\alpha]_{\mathrm{D}}{ }^{25}=-14.7\left(c 0.83, \mathrm{CH}_{2} \mathrm{Cl}_{2}, 50 \%\right.$ ee) $\left\{\right.$ lit. [91], $[\alpha]_{\mathrm{D}}{ }^{20}-27.8\left(c 1.1, \mathrm{CH}_{2} \mathrm{Cl}_{2}\right.$, for $(S)-8 \mathbf{b a}, 90 \%$ ee $\}$.

(S)-5-fluoro-3-(2-nitro-1-phenylethyl)-1H-indole (8ca) [47]. Following the general procedure, compound 8ca was obtained after 3 days of reaction at room temperature in $43 \%$ yield. The ee of the product was determined to be $53 \%$ by HPLC using a Daicel Chiralpak IA column ( $n$-hexane $/ i-\mathrm{PrOH}=90: 10$, flow rate $1 \mathrm{~mL} \cdot \mathrm{min}^{-1}, \lambda=254.0 \mathrm{~nm}$ ): $\tau_{\text {major }}=13.7 \mathrm{~min} ; \tau_{\text {minor }}=12.2 \mathrm{~min}$. $[\alpha]_{\mathrm{D}}^{25}=+6.3\left(c 0.92, \mathrm{CHCl}_{3}, 53 \%\right.$ ee) $\left\{\right.$ lit. [ [47], $[\alpha]_{\mathrm{D}}{ }^{26}+11\left(c 0.38, \mathrm{CHCl}_{3}\right.$, for $(S)-8 \mathrm{ca}, 86 \%$ ee $\}$.

(S)-5-methoxi-3-(2-nitro-1-phenylethyl)-1H-indole (8da) [53]. Following the general procedure, compound $8 \mathrm{da}$ was obtained after 3 days of reaction at room temperature in $98 \%$ yield. The ee of the product was determined to be $55 \%$ by HPLC using a Daicel Chiralpak IA column ( $n$-hexane $/ i-\mathrm{PrOH}=90: 10$, flow rate $1 \mathrm{~mL} \cdot \mathrm{min}^{-1}, \lambda=254.0 \mathrm{~nm}$ ): $\tau_{\text {major }}=20.4 \mathrm{~min} ; \tau_{\text {minor }}=17.1 \mathrm{~min}$. $[\alpha]_{\mathrm{D}}^{23}=-15.5\left(c 0.34, \mathrm{CH}_{2} \mathrm{Cl}_{2}, 55 \%\right.$ ee) \{lit. [53], $[\alpha]_{\mathrm{D}}{ }^{20}-28.4$ (c 1.0, $\mathrm{CH}_{2} \mathrm{Cl}_{2}$, for (S)-8da, $98 \%$ ee $\}$. 


\subsection{Evaluation of the Stability of Urea Aggregates}

Thermoreversible gels ( $1 \mathrm{~mL}$ volume) were prepared at desired concentration by the gentle heating-cooling procedure, as previously described [47]. Unless stated otherwise, acid additives (from a stock solution) were mixed with the urea and the volume was then adjusted with pure solvent. The heating-cooling cycle was then applied and the formed gels were considered to be stable if they did not exhibit gravitational flow upon turning the vial upside-down. See Supporting Information for additional details.

Unless indicated otherwise, gels were equilibrated for at least overnight at room temperature before thermal analysis. $T_{\text {gel }}$ values were determined at desired times after gelation using a calibrated thermoblock, which was heated using an electric heating plate equipped with a temperature control couple at $\sim 0.4^{\circ} \mathrm{C} / \mathrm{min}$ [47]. The temperature at which the bulk gel started to break was defined as $T_{\text {gel }}$. Each measurement was randomly made at least twice and the average value was reported with an estimated error of $\pm 2{ }^{\circ} \mathrm{C}$. Reported $T_{\text {gel }}$ values correspond to the gel phase that supported the inversion of the vial, which enabled separation first of any liquid phase generated by the acid additive.

Flow properties of our compounds were studied by oscillatory rheology using an AR 2000 Advanced rheometer (TA Instruments, Regensburg, Germany) equipped with a Julabo C cooling system (Regensburg, Germany). A $1000 \mathrm{~mm}$ gap setting and a torque of $5 \times 10^{-4} \mathrm{~N} / \mathrm{m}$ at $25^{\circ} \mathrm{C}$ were employed for the measurements in a plain-plate $(20 \mathrm{~mm}$, stainless steel). The following experiments were performed for each sample, using $2 \mathrm{~mL}$ total gel volume: (a) Dynamic strain sweep $($ DSS $)=$ variation of storage modulus $G^{\prime}$ and loss modulus $G^{\prime \prime}$ with strain from 0.01 to $100 \%$; (b) dynamic frequency sweep (DFS) = variation of $G^{\prime}$ and $G^{\prime \prime}$ with frequency from 0.1 to $10 \mathrm{~Hz}$ at $0.1 \%$ strain; (c) dynamic time sweep (DTS) = variation of $G^{\prime}$ and $G^{\prime \prime}$ with time keeping the strain and frequency values constant and within the linear viscoelastic regime (i.e., strain $=0.1 \%$ strain; frequency $=1 \mathrm{~Hz}$ ). Mechanical inertial effects of the measuring head were determined by the software package. In addition, fixed rest time after sample loading and pre-shearing to equilibrium at different shear rates were routinely made in order to minimize prehistory effects.

Field Emission Scanning Electron Microscopy (FESEM) images of xerogels were recorded with a Zeiss Merlin, Field Emission Scanning Electron Microscope (Zaragoza, Spain) operated at an accelerating voltage of $10 \mathrm{kV}$. For visualization, samples were prepared by freeze-drying the corresponding gels. The obtained fibrous solids were placed on top of tin plates and shielded with $\mathrm{Pt}$ ( $40 \mathrm{~mA}$ during 30-60 s; film thickness $=5-10 \mathrm{~nm}$ ). Images were taken at the University of Zaragoza (Servicio General de Apoyo a la Investigación-SAI)

\section{Conclusions}

The results obtained in the Friedel-Crafts alkylation reaction suggest that the synergic effect between a Brønsted acid and a urea catalyst is higher than the effect promoted by each species separately. The experiments are also in agreement first, with the critical role played by the free carboxylic group in the disassembly of the supramolecular urea aggregates and secondly, in the activation of the "free" urea through coordination by the acid. This mechanism was demonstrated by analyzing the thermal and mechanical stability, as well as morphological properties of the supramolecular gel aggregates in the absence and presence of acid additives at different molar ratios. In terms of the effect of different acids, the most remarkable outcome (i.e., decrease of gel stability and significant changes in morphology) was observed with mandelic acid, which prevented the gelation at molar ratio of 0.9. In contrast, experiments using the corresponding methyl ester caused minor disruption in the gel, in good agreement with the observations made during the catalytic studies.

The observed behavior is studied for the first time in the literature and could open a new interesting research line related to the effect of acid on urea-catalyzed reactions. Moreover, this contribution could become an important starting point for further investigations, since this study suggests that this phenomenon could be extended to other molecules with similar acidity and/or hydrogen-bonding ability. This possibility is currently being investigated in our laboratories. 
Supplementary Materials: The following are available online at http:/ /www.mdpi.com/2073-4344/8/8/305/s1, Scheme S1: pKa values in waters, Figures S1-S8: Effect of the acid in the ${ }^{1} \mathrm{H}$ NMR signals of the urea catalysts (500 MHz), Figures S9-S44: HPLC chromatograms, Figure S45: Gel measurements, Table S1: Effects of the addition of different additives on the aspect, gelation time and $T_{\text {gel }}$ with respect to the pristine gels prepared in $\mathrm{CHCl}_{3}$ and in toluene.

Author Contributions: Conceptualization, E.M.-L., D.D.D. and R.P.H.; Methodology, Software, Validation, Formal Analysis, Investigation, Resources, Data Curation, all authors; Writing-Original Draft Preparation, D.D.D. and R.P.H.; Writing-Review \& Editing, all authors; Visualization, E.M.-L., D.D.D. and R.P.H.; Supervision, E.M.-L., D.D.D. and R.P.H.; Project Administration, E.M.-L., D.D.D. and R.P.H.; Funding Acquisition, E.M.-L., D.D.D. and R.P.H.

Funding: This research was funded by Ministerio de Economía, Industria y Competitividad (CTQ2017-88091-P), Universidad de Zaragoza (JIUZ-2017-CIE-05) and Gobierno de Aragón-Fondo Social Europe (Research Groups E-07_17R).

Acknowledgments: I. G. S. thanks the Obra Social de Ibercaja-CAI for mobility aid. D. D. D. thanks the Deutsche Forschungsgemeinschaft (DFG) for the Heisenberg Professorship Award.

Conflicts of Interest: The authors declare no conflict of interest.

\section{References}

1. Berkessel, A.; Gröger, H. Asymmetric Organocatalysis; Whiley-VHC: Weinheim, Germany, 2004.

2. Acc. Chem. Res. 2004, 37 (8). Special Issue on Organocatalysis; Houk, K.N., List, B., Eds.; American Chemical Society: Washington, DC, USA, 2004.

3. Enantioselective Organocatalysis; Dalko, P.I., Ed.; Whiley-VCH: Weinheim, Germany, 2007.

4. Chem. Rev. 2007, 107 (12). Special Issue on Organocatalysis; List, B., Ed.; American Chemical Society: Washington, DC, USA, 2007.

5. Recent Developments in Asymmetric Organocatalysis; Pellissier, H., Ed.; RSC Publishing: Cambridge, UK, 2010.

6. Asymmetric Organocatalysis; List, B., Ed.; Springer: Heidelberg, Germany, 2010.

7. Current Organic Chemistry, Volume 15, Number 13; Herrera, R.P., Ed.; Bentham Science: Soest, The Netherlands, 2011.

8. Science of Synthesis Asymmetric Organocatalysis; List, B.; Maruoka, K., Eds.; Thieme: Sttutgart, Germany, 2012.

9. Comprehensive Enantioselective Organocatalysis: Catalysts, Reactions, and Application; Dalko, P.I., Ed.; Wiley-VCH: Weinheim, Germany, 2013.

10. De Figueiredo, R.M.; Christmann, M. Organocatalytic Synthesis of Drugs and Bioactive Natural Products. Eur. J. Org. Chem. 2007, 2007, 2575-2600. [CrossRef]

11. Marqués-López, E.; Herrera, R.P.; Christmann, M. Asymmetric organocatalysis in total synthesis-A trial by fire. Nat. Prod. Rep. 2010, 27, 1138-1167. [CrossRef] [PubMed]

12. Alemán, J.; Cabrera, S. Applications of asymmetric organocatalysis in medicinal chemistry. Chem. Soc. Rev. 2013, 42, 774-793. [CrossRef] [PubMed]

13. Marqués-López, E.; Herrera, R.P. Comprehensive Enantioselective Organocatalysis; Dalko, P., Ed.; Wiley-VCH: Weinheim, Germany, 2013; pp. 1359-1383.

14. Dalko, P.I.; Mosan, L. In the Golden Age of Organocatalysis. Angew. Chem. Int. Ed. 2004, 43, 5138-5175. [CrossRef] [PubMed]

15. Berkessel, A. Organocatalysis by Hydrogen Bonding Networks in Organocatalysis; Reetz, M.T., List, B., Jaroch, H., Weinmann, H., Eds.; Springer: Berlin, Germany, 2008; Volume 2, pp. 281-297.

16. Hydrogen Bonding in Organic Synthesis; Pihko, P.M., Ed.; Wiley-VCH: Weinheim, Germany, 2009.

17. Kerstin, E.-E.; Berkessel, A. Noncovalent organocatalysis based on hydrogen bonding: elucidation of reaction paths by computational methods. Top. Curr. Chem. 2010, 291, 1-27. [CrossRef]

18. Schreiner, P.R. Metal-free organocatalysis through explicit hydrogen bonding interactions. Chem. Soc. Rev. 2003, 32, 289-296. [CrossRef] [PubMed]

19. Takemoto, Y. Recognition and activation by ureas and thioureas: stereoselective reactions using ureas and thioureas as hydrogen-bonding donors. Org. Biomol. Chem. 2005, 3, 4299-4306. [CrossRef] [PubMed]

20. Connon, S.J. Organocatalysis Mediated by (Thio)urea Derivatives. Chem. Eur. J. 2006, 12, 5418-5429. [CrossRef] [PubMed]

21. Taylor, M.S.; Jacobsen, E.N. Asymmetric Catalysis by Chiral Hydrogen-Bond Donors. Angew. Chem. Int. Ed. 2006, 45, 1520-1543. [CrossRef] [PubMed]

22. Doyle, A.G.; Jacobsen, E.N. Small-Molecule H-Bond Donors in Asymmetric Catalysis. Chem. Rev. 2007, 107, 5713-5743. [CrossRef] [PubMed] 
23. Miyabe, H.; Takemoto, Y. Discovery and Application of Asymmetric Reaction by Multi-Functional Thioureas. Bull. Chem. Soc. Jpn. 2008, 81, 785-795. [CrossRef]

24. Zhang, Z.; Schreiner, P.R. (Thio)urea organocatalysis-What can be learnt from anion recognition? Chem. Soc. Rev. 2009, 38, 1187-1198. [CrossRef] [PubMed]

25. Marqués-López, E.; Herrera, R.P. El renacer de un nuevo campo: La Organocatálisis Asimétrica. Tioureas como organocatalizadores. An. Quim. 2009, 105, 5-12. (In Spanish)

26. Takemoto, Y. Development of Chiral Thiourea Catalysts and Its Application to Asymmetric Catalytic Reactions. Chem. Pharm. Bull. 2010, 58, 593-601. [CrossRef] [PubMed]

27. Sohtome, Y.; Nagasawa, K. The Design of Chiral Double Hydrogen Bonding Networks and Their Applications to Catalytic Asymmetric Carbon-Carbon and Carbon-Oxygen Bond-Forming Reactions. Synlett 2010, 1-22. [CrossRef]

28. Sohtome, Y.; Nagasawa, K. Dynamic asymmetric organocatalysis: Cooperative effects of weak interactions and conformational flexibility in asymmetric organocatalysts. Chem. Commun. 2012, 48, 7777-7789. [CrossRef] [PubMed]

29. Marqués-López, E.; Herrera, R.P. New Strategies in Chemical Synthesis and Catalysis; Pignataro, B., Ed.; Wiley-VCH: Weinheim, Germany, 2012; pp. 175-199.

30. Serdyuk, O.V.; Heckel, C.M.; Tsogoeva, S.B. Bifunctional primary amine-thioureas in asymmetric organocatalysis. Org. Biomol. Chem. 2013, 11, 7051-7071. [CrossRef] [PubMed]

31. Xi, Y.; Shi, X. Cinchonine and thiourea. Chem. Commun. 2013, 49, 8583-8585. [CrossRef] [PubMed]

32. Narayanaperumal, S.; Rivera, D.G.; Silva, R.C.; Paixão, M.W. Terpene-Derived Bifunctional Thioureas in Asymmetric Organocatalysis. ChemCatChem. 2013, 5, 2756-2773. [CrossRef]

33. Zhang, Z.; Bao, Z.; Xing, H. N,N'-Bis[3,5-bis(trifluoromethyl)phenyl]thiourea: a privileged motif for catalyst development. Org. Biomol. Chem. 2014, 12, 3151-3162. [CrossRef] [PubMed]

34. Fang, X.; Wang, C.-J. Recent advances in asymmetric organocatalysis mediated by bifunctional amine-thioureas bearing multiple hydrogen-bonding donors. Chem. Commun. 2015, 51, 1185-1197. [CrossRef] [PubMed]

35. Curran, D.P.; Kuo, L.H. Altering the Stereochemistry of Allylation Reactions of Cyclic. alpha.-Sulfinyl Radicals with Diarylureas. J. Org. Chem. 1994, 59, 3259-3261. [CrossRef]

36. Curran, D.P.; Kuo, L.H. Acceleration of a dipolar Claisen rearrangement by Hydrogen bonding to a soluble diaryl^urea. Tetrahedron Lett. 1995, 36, 6647-6650. [CrossRef]

37. Etter, M.C.; Panunto, T.W. 1,3-Bis(m-nitrophenyl)urea: An exceptionally good complexing agent for proton acceptors. J. Am. Chem. Soc. 1988, 110, 5896-5897. [CrossRef]

38. Etter, M.C.; Urbañczyk-Lipkowska, Z.; Zia-Ebrahimi, M.; Panunto, T.W. Hydrogen bond-directed cocrystallization and molecular recognition properties of diarylureas. J. Am. Chem. Soc. 1990, 112, 8415-8426. [CrossRef]

39. Etter, M.C. Encoding and decoding hydrogen-bond patterns of organic compounds. Acc. Chem. Res. 1990, 23, 120-126. [CrossRef]

40. Kelly, T.R.; Kim, M.H. Relative Binding Affinity of Carboxylate and Its Isosteres: Nitro, Phosphate, Phosphonate, Sulfonate, and. delta.-Lactone. J. Am. Chem. Soc. 1994, 116, 7072-7080. [CrossRef]

41. Auvil, T.J.; Schafer, A.G.; Mattson, A.E. Design Strategies for Enhanced Hydrogen-Bond Donor Catalysts. Eur. J. Org. Chem. 2014, 2633-2646. [CrossRef]

42. Giacalone, F.; Gruttadauria, M.; Agrigento, P.; Noto, R. Low-loading asymmetric organocatalysis. Chem. Soc. Rev. 2012, 41, 2406-2447. [CrossRef] [PubMed]

43. Herrera, R.P.; Sgarzani, V.; Bernardi, L.; Ricci, A. Catalytic enantioselective Friedel-Crafts alkylation of indoles with nitroalkenes by using a simple thiourea organocatalyst. Angew. Chem. Int. Ed. 2005, 44, 6734-6737. [CrossRef] [PubMed]

44. Herrera, R.P.; Monge, D.; Martín-Zamora, E.; Fernández, R.; Lassaletta, J.M. Organocatalytic Conjugate Addition of Formaldehyde $N, N$-Dialkylhydrazones to $\beta, \gamma$-Unsaturated $\alpha$-Keto Esters. Org. Lett. 2007, 9 , 3303-3306. [CrossRef] [PubMed]

45. Marqués-López, E.; Alcaine, A.; Tejero, T.; Herrera, R.P. Enhanced Efficiency of Thiourea Catalysts by External Brønsted Acids in the Friedel—Crafts Alkylation of Indoles. Eur. J. Org. Chem. 2011, 3700-3705. [CrossRef] 
46. Roca-López, D.; Marqués-López, E.; Alcaine, A.; Merino, P.; Herrera, R.P. A Friedel-Crafts alkylation mechanism using an aminoindanol-derived thiourea catalyst. Org. Biomol. Chem. 2014, 12, 4503-4510. [CrossRef] [PubMed]

47. Schön, E.-M.; Marqués-López, E.; Herrera, R.P.; Alemán, C.; Díaz, D.D. Exploiting Molecular Self-Assembly: From Urea-Based Organocatalysts to Multifunctional Supramolecular Gels. Chem. Eur. J. 2014, 20, 10720-10731. [CrossRef] [PubMed]

48. Juste-Navarro, V.; Marqués-López, E.; Herrera, R.P. Thiourea-Catalyzed Addition of Indoles to Aliphatic $\beta, \gamma$-Unsaturated $\alpha$-Ketoesters. Asian J. Org. Chem. 2015, 4, 884-889. [CrossRef]

49. Schiller, J.; Pérez-Ruiz, R.; Sampedro, D.; Marqués-López, E.; Herrera, R.P.; Díaz, D.D. Fluoride Anion Recognition by a Multifunctional Urea Derivative: An Experimental and Theoretical Study. Sensors 2016, 16, 658. [CrossRef] [PubMed]

50. Gimeno, M.C.; Herrera, R.P. Hydrogen Bonding Networks in Chiral Thiourea Organocatalysts: Evidence on the Importance of the Aminoindanol Moiety. Cryst. Growth Des. 2016, 16, 5091-5099. [CrossRef]

51. Izaga, A.; Herrera, R.P.; Gimeno, M.C. Gold(I)-Mediated Thiourea Organocatalyst Activation: A Synergic Effect for Asymmetric Catalysis. ChemCatChem 2017, 9, 1313-1321. [CrossRef] [PubMed]

52. Robak, M.T.; Trincado, M.; Ellman, J.A. Enantioselective Aza-Henry Reaction with an N-Sulfinyl Urea Organocatalyst. J. Am. Chem. Soc. 2007, 129, 15110-15111. [CrossRef] [PubMed]

53. Ganesh, M.; Seidel, D. Catalytic Enantioselective Additions of Indoles to Nitroalkenes. J. Am. Chem. Soc. 2008, 130, 16464-16465. [CrossRef] [PubMed]

54. So, S.; Burkett, J.A.; Mattson, A.E. Internal Lewis Acid Assisted Hydrogen Bond Donor Catalysis. Org. Lett. 2011, 13, 716-719. [CrossRef] [PubMed]

55. Sonsona, I.G.; Marqués-López, E.; Herrera, R.P. The aminoindanol core as a key scaffold in bifunctional organocatalysts. Beilstein J. Org. Chem. 2016, 12, 505-523. [CrossRef] [PubMed]

56. Fan, Y.; Kass, S.R. Enantioselective Friedel-Crafts Alkylation between Nitroalkenes and Indoles Catalyzed by Charge Activated Thiourea Organocatalysts. J. Org. Chem. 2017, 82, 13288-13296. [CrossRef] [PubMed]

57. Jensen, K.H.; Sigman, M.S. Systematically Probing the Effect of Catalyst Acidity in a Hydrogen-Bond-Catalyzed Enantioselective Reaction. Angew. Chem. Int. Ed. 2007, 46, 4748-4750. [CrossRef] [PubMed]

58. Marqués-López, E.; Diez-Martinez, A.; Merino, P.; Herrera, R.P. The Role of the Indole in Important Organocatalytic Enantioselective Friedel-Crafts Alkylation Reactions. Curr. Org. Chem. 2009, 13, 1585-1609. [CrossRef]

59. You, S.-L.; Cai, Q.; Zeng, M. Chiral Brønsted acid catalyzed Friedel-Crafts alkylation reactions. Chem. Soc. Rev. 2009, 38, 2190-2210. [CrossRef] [PubMed]

60. Terrasson, V.; de Figueiredo, R.M.; Campagne, J.M. Organocatalyzed Asymmetric Friedel-Crafts Reactions. Eur. J. Org. Chem. 2010, 2635-2655. [CrossRef]

61. Zeng, M.; You, S.-L. Asymmetric Friedel-Crafts Alkylation of Indoles: The Control of Enantio- and Regioselectivity. Synlett 2010, 1289-1301. [CrossRef]

62. Dessole, G.; Herrera, R.P.; Ricci, A. H-Bonding Organocatalysed Friedel-Crafts Alkylation of Aromatic and Heteroaromatic Systems with Nitroolefins. Synlett 2004, 2374-2378. [CrossRef]

63. Pettersen, D.; Herrera, R.P.; Bernardi, L.; Fini, F.; Sgarzani, V.; Fernández, R.; Lassaletta, J.M.; Ricci, A. A Broadened Scope for the Use of Hydrazones as Neutral Nucleophiles in the Presence of H-Bonding Organocatalysts. Synlett 2006, 239-242. [CrossRef]

64. Bernardi, L.; Fini, F.; Herrera, R.P.; Ricci, A.; Sgarzani, V. Enantioselective aza-Henry reaction using cinchona organocatalysts. Tetrahedron 2006, 62, 375-380. [CrossRef]

65. Alcaine, A.; Marqués-López, E.; Merino, P.; Tejero, T.; Herrera, R.P. Thiourea catalyzed organocatalytic enantioselective Michael addition of diphenyl phosphite to nitroalkenes. Org. Biomol. Chem. 2011, 9, 2777-2783. [CrossRef] [PubMed]

66. Auria-Luna, F.; Marqués-López, E.; Mohammadi, S.; Heiran, R.; Herrera, R.P. New Organocatalytic Asymmetric Synthesis of Highly Substituted Chiral 2-Oxospiro-[indole-3,4'-(1', $4^{\prime}$-dihydropyridine)] Derivatives. Molecules 2015, 20, 15807-15826. [CrossRef] [PubMed]

67. Bordwell, F.G.; Algrim, D.J.; Harrelson, J.A., Jr. The relative ease of removing a proton, a hydrogen atom, or an electron from carboxamides versus thiocarboxamides. J. Am. Chem. Soc. 1988, 110, 5903-5904. [CrossRef] 
68. This behavior can be also rationalized in terms of ab initio methods, which support differences in energy for the $\mathrm{N}-\mathrm{H}$-..S compared with $\mathrm{N}-\mathrm{H}$.. O interaction in the chain dimers, being weaker in thioureas than in ureas (Ref. 69 and 70).

69. Masunov, A.; Dannenberg, J.J. Theoretical Study of Urea. I. Monomers and Dimers. J. Phys. Chem. A 1999, 103, 178-184. [CrossRef]

70. Masunov, A.; Dannenberg, J.J. Theoretical Study of Urea and Thiourea. 2. Chains and Ribbons. J. Phys. Chem. B 2000, 104, 806-810. [CrossRef]

71. Berkessel, A.; Cleemann, F.; Mukherjee, S.; Müller, T.N.; Lex, J. Highly Efficient Dynamic Kinetic Resolution of Azlactones by Urea-Based Bifunctional Organocatalysts. Angew. Chem. Int. Ed. 2005, 44, 807-811. [CrossRef] [PubMed]

72. Scheerder, J.; Engbersen, J.F.J.; Casnati, A.; Ungaro, R.; Reinhoudt, D.N. Complexation of Halide Anions and Tricarboxylate Anions by Neutral Urea-Derivatized p-tert-Butylcalix[6]arenes. J. Org. Chem. 1995, 60, 6448-6454. [CrossRef]

73. Weil, T.; Kotke, M.; Kleiner, C.M.; Schreiner, P.R. Cooperative Brønsted Acid-Type Organocatalysis: Alcoholysis of Styrene Oxides. Org. Lett. 2008, 10, 1513-1516. [CrossRef] [PubMed]

74. Companyó, X.; Valero, G.; Crovetto, L.; Moyano, A.; Rios, R. Highly Enantio- and Diastereoselective Organocatalytic Desymmetrization of Prochiral Cyclohexanones by Simple Direct Aldol Reaction Catalyzed by Proline. Chem. Eur. J. 2009, 15, 6564-6568. [CrossRef] [PubMed]

75. Reis, Ö.; Eymur, S.; Reis, B.; Demir, A.S. Direct enantioselective aldol reactions catalyzed by a proline-thiourea host-guest complex. Chem. Commun. 2009, 1088-1090. [CrossRef] [PubMed]

76. El-Hamdouni, N.; Companyó, X.; Rios, R.; Moyano, A. Substrate-Dependent Nonlinear Effects in Proline-Thiourea-Catalyzed Aldol Reactions: Unraveling the Role of the Thiourea Co-Catalyst. Chem. Eur. J. 2010, 16, 1142-1148. [CrossRef] [PubMed]

77. Klausen, R.S.; Jacobsen, E.N. Weak Brønsted Acid-Thiourea Co-catalysis: Enantioselective, Catalytic Protio-Pictet-Spengler Reactions. Org. Lett. 2009, 11, 887-890. [CrossRef] [PubMed]

78. Xu, H.; Zuend, S.J.; Woll, M.G.; Tao, Y.; Jacobsen, E.N. Asymmetric Cooperative Catalysis of Strong Brønsted Acid-Promoted Reactions Using Chiral Ureas. Science 2010, 327, 986-990. [CrossRef] [PubMed]

79. Shi, Y.-L.; Shi, M. Chiral Thiourea-Phosphine Organocatalysts in the Asymmetric Aza-Morita-Baylis-Hillman Reaction. Adv. Synth. Catal. 2007, 349, 2129-2135. [CrossRef]

80. Escuder, B.; LLusar, M.; Miravet, J.F. Insight on the NMR Study of Supramolecular Gels and Its Application to Monitor Molecular Recognition on Self-Assembled Fibers. J. Org. Chem. 2006, 71, 7747-7752. [CrossRef] [PubMed]

81. Schoonbeek, F.S.; van Esch, J.H.; Hulst, R.; Kellogg, R.M.; Feringa, B.L. Geminal Bis-ureas as Gelators for Organic Solvents: Gelation Properties and Structural Studies in Solution and in the Gel State. Chem. Eur. J. 2000, 6, 2633-2643. [CrossRef]

82. Jung, J.H.; Shinkai, S.; Shimizu, T. Spectral Characterization of Self-Assemblies of Aldopyranoside Amphiphilic Gelators: What is the Essential Structural Difference Between Simple Amphiphiles and Bolaamphiphiles? Chem. Eur. J. 2002, 8, 2684-2690. [CrossRef]

83. Morris, K.F.; Johnson, C.S., Jr. Diffusion-ordered two-dimensional nuclear magnetic resonance spectroscopy. J. Am. Chem. Soc. 1992, 114, 3139-3141. [CrossRef]

84. Price, W.S. Pulsed-field gradient nuclear magnetic resonance as a tool for studying translational iffusion: Part 1. Basic theory. Conc. Magn. Reson. 1997, 9, 299-336. [CrossRef]

85. Cohen, Y.; Avram, L.; Frish, L. Diffusion NMR Spectroscopy in Supramolecular and Combinatorial Chemistry: An Old Parameter-New Insights. Angew. Chem. Int. Ed. 2005, 44, 520-554. [CrossRef] [PubMed]

86. Reactive Intermediates; Santos, L.S., Ed.; Wiley-VCH: Weinheim, Germany, 2010.

87. Liu, X.-G.; Jiang, J.-J.; Shia, M. Development of axially chiral bis(arylthiourea)-based organocatalysts and their application in the enantioselective Henry reaction. Tetrahedron: Asymmetry 2007, 18, 2773-2781. [CrossRef]

88. Jia, Y.-X.; Zhu, S.-F.; Yang, Y.; Zhou, Q.-L. Asymmetric Friedel-Crafts Alkylations of Indoles with Nitroalkenes Catalyzed by Zn(II)-Bisoxazoline Complexes. J. Org. Chem. 2006, 71, 75-80. [CrossRef] [PubMed]

89. Meshram, H.M.; Rao, N.N.; Kumar, G.S. Boric Acid-Mediated Mild and Efficient Friedel-Crafts Alkylation of Indoles with Nitro Styrenes. Synth. Commun. 2010, 40, 3496-3500. [CrossRef] 
90. Wu, J.; Li, X.; Wu, F.; Wan, B. A New Type of Bis(sulfonamide)-Diamine Ligand for a Cu(OTf) $)_{2}$-Catalyzed Asymmetric Friedel-Crafts Alkylation Reaction of Indoles with Nitroalkenes. Org. Lett. 2011, 13, 4834-4837. [CrossRef] [PubMed]

91. Itoh, J.; Fuchibe, K.; Akiyama, T. Chiral Phosphoric Acid Catalyzed Enantioselective Friedel-Crafts Alkylation of Indoles with Nitroalkenes: Cooperative Effect of $3 \AA$ A Molecular Sieves. Angew. Chem. Int. Ed. 2008, 47, 4016-4018. [CrossRef] [PubMed] 